\title{
SUSTAINABLE DEVELOPMENT IMPACTS OF RENEWABLE POWER: INSIGHTS FROM THREE INDIAN STATES
}

\section{EXECUTIVE SUMMARY}

\section{Highlights}

- As India scales its renewable energy (RE) capacity, it is critical that RE technologies be deployed considering their context-specific socioeconomic and environmental impacts. We estimate the economic rate of return (ERR) associated with prominent RE technologies, including the impacts (relative to a coal baseline) on health, water, land, and climate, in three Indian states: Maharashtra, Jharkhand, and Assam.

- The technologies assessed include solar photovoltaic and small hydro power (SHP) for all three states, and wind for Maharashtra. Maharashtra has the highest ERR for all the assessed technologies, followed by Jharkhand and Assam. Wind yields the highest returns in Maharashtra, solar photovoltaic (PV) in Jharkhand, and SHP in Assam.

- Local factors, such as the prevailing population and land-use patterns, water scarcity, and weather conditions, play a vital role in driving the ERR estimates. Comparing our ERR estimates against a social discount rate value of 8 percent shows that all the assessed RE technologies, except solar PV in Assam, provide a sufficiently high return to society to justify public investment.

- Although not all impacts can be economically quantified, the ERR can help policymakers prioritize the right $\mathrm{RE}$ technologies for a region and formulate policies that enhance the societal benefits of RE deployment.

\section{CONTENTS}

Executive Summary 1

1. Introduction .......................................... 4

2. Assessment Methodology ......................... 6

3. Results and Insights ...............................16

Appendix A: Quantification of Health Impacts ........... 22

Appendix B: Quantification of Water Impacts............ 27

Appendix C: Quantification of Land Impacts ............. 29

Appendix D: Quantification of Climate Impacts ........... 33

Appendix E: Technology Assumptions .................... 35

Appendix F: Sensitivity Analysis ........................ 38

References ............................................ 41

Working Papers contain preliminary research, analysis, findings, and recommendations. They are circulated to stimulate timely discussion and critical feedback and to influence ongoing debate on emerging issues. Most working papers are eventually published in another form and their content may be revised.

Suggested Citation: Kulkarni, T., A. Hingne, V. Agarwal, and J. C. Altamirano. 2021. "Sustainable Development Impacts of Renewable Power: Insights from Three Indian States.” Working Paper. Washington, DC: World Resources Institute. Available online at https://doi.org/10.46830/wriwp.20.00109. 


\section{Context}

RE will play a vital role in decarbonizing the world's energy supply. With the recently announced target of scaling non-fossil installed capacity to 500 gigawatts (GW) by 2030 (PIB 2021), renewables form the cornerstone of India's climate goals and future energy mix. Although RE offers a host of economic, social, and environmental co-benefits, it also entails costs to society, such as the use of land, water, and other scarce resources. To truly harness the societal benefits of $\mathrm{RE}$ technologies, they need to be deployed considering the full spectrum of their context-specific environmental and socioeconomic impacts, along with measures to mitigate these impacts.

\section{About This Paper}

WRI's Framework to Assess the Sustainable Development Impacts of Renewable Power Technologies (the Sustainable Development [SD] Framework) provides a structured approach to identifying and, where feasible, quantifying the environmental and socioeconomic impacts of RE deployment, combining them into a convenient metric to support decision-making (see Figure ES-1). In our previous research, we applied the SD Framework to evaluate the economic returns of prominent renewable technologies in India (Hingne et al. 2020). Although a national-level assessment provides a broad indication of the relative returns for these technologies, impact estimates depend greatly on the local geography, prevailing environmental and social conditions, and specific deployment parameters, for example, the type of land diverted for a project. Therefore, taking the national-level analysis further, we estimate the ERR for renewable technologies at the state level in this paper. We choose Maharashtra, Jharkhand, and Assam for the assessment, which represent different levels of RE penetration, diverse geographic conditions, as well as contrasting environmental and socioeconomic conditions.

In our ERR estimates, we consider the health, water, land, and climate impacts of RE deployment, along with traditional cashflows, such as capital and operations and maintenance (O\&M) costs, relative to a coal baseline over a generation period of 25 years. The calculations are based on the current performance norms for each technology and use state-specific data, wherever available.

However, our ERR estimates provide only an exante projection of the generation-phase impacts of RE technology deployment. Including impacts across technology lifecycles will yield different results, and these should be considered where it is relevant and feasible. Furthermore, the realization of estimated returns depends on the deployment parameters on the ground, which can vary from the average or current norms assumed in our calculations. The ERR estimates also depend upon the economic valuation of non-market indicators, which can vary significantly depending on the methods and assumptions used for the valuation, to which careful attention should be paid in interpreting the results. Finally, some relevant impacts, namely, employment, energy security, and certain ecological impacts, are not captured in our quantitative estimates. We recommend that decisionmakers consider these on a case-to-case basis, at least qualitatively, in conjunction with the ERR numbers.

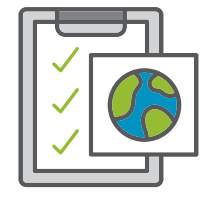

Identify objectives of assessing SD impacts of renewable energy (RE) technologies

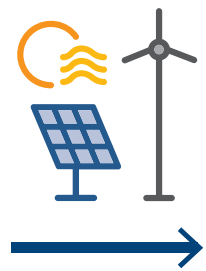

Determine RE technologies to be assessed and the baseline technology

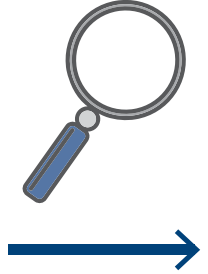

Identify relevant impact categories and indicators

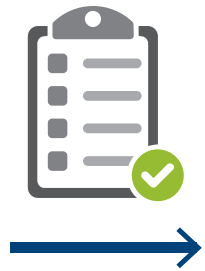

Quantify and assign economic value to SD impacts

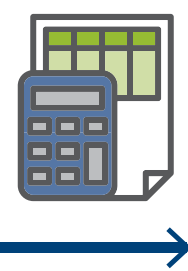

Calculate the economic rate of return (ERR) of RE technologies

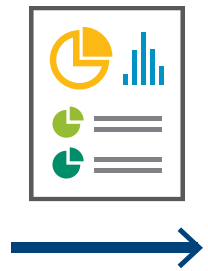

Report assessment results

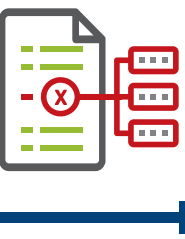

Report SD impacts not included in estimation of ERR 


\section{Key Findings}

- Among the three states, all RE technologies assessed yield the highest ERR in Maharashtra, indicating that RE deployment in the state provides the maximum relative socioeconomic returns to society. ERR estimates in the state are driven by a high capacity utilization factor (CUF) for RE technologies owing to favorable weather conditions, as well as avoided water-use impacts from RE deployment, which are the highest among the three states assessed due to water scarcity in Maharashtra.

- Avoided health impacts from reduced air pollution drive the ERR for RE technologies in Jharkhand because of a higher population density in the state. Jharkhand sees relatively high ERR estimates across all three technologies (comparable to the national average), although lower than that in Maharashtra.

- Relative to Maharashtra and Jharkhand, our estimates suggest that the lowest ERR from RE technologies is found in Assam. This is primarily because of the lower avoided health and water-use impacts, due to the low population density and the relative abundance of water in the state, respectively. Figure ES-2 presents the state-wise ERR for each assessed technology. We also assessed the ERR relative to a gas baseline for Assam as a supplementary scenario, given its historical prevalence in the state, and found it to be negative for all RE technologies.

- Except for land, a net benefit relative to a coal baseline is seen for all the other impact categories assessed-health, water, and climate-for all of the RE technologies assessed in all the three states (with the exception of rooftop solar PV, which is the only RE technology that also provides a net land-use benefit).

- Comparing the ERR value against a social discount rate-the hurdle rate for public investment in welfare-of 8 percent for India (Murty et al. 2020), we find that all the assessed RE technologies, except solar PV in the case of Assam, provide a sufficiently high return to society (relative to a coal baseline) under current technology and performance norms, justifying public investment in these technologies where private investment is not financially viable. In the case of solar PV in Assam, excluding grid integration costs from our estimates increases the rate of return sufficiently to meet this acceptability criterion.

- A comparison of the regional RE returns assessed here with the national-level average ERR from Hingne et al. (2020) indicates that national average returns do not capture the regional variation in the relative SD impacts and therefore in the economic returns of RE deployment, highlighting the need for context-specific application of the SD Framework.

\section{Implications for Policy and the Way Forward}

As seen from our analysis for Maharashtra, Jharkhand, and Assam, a comparative assessment of ERR estimates for different RE technologies within a state can enable local policymakers to prioritize the right $R E$ technologies for deployment. The use of ERR estimates in decision-making, for example, as one of the metrics for the selection of bids for allocation of public projects

Figure ES-2 | Estimated ERR for RE Technologies at State and National Levels

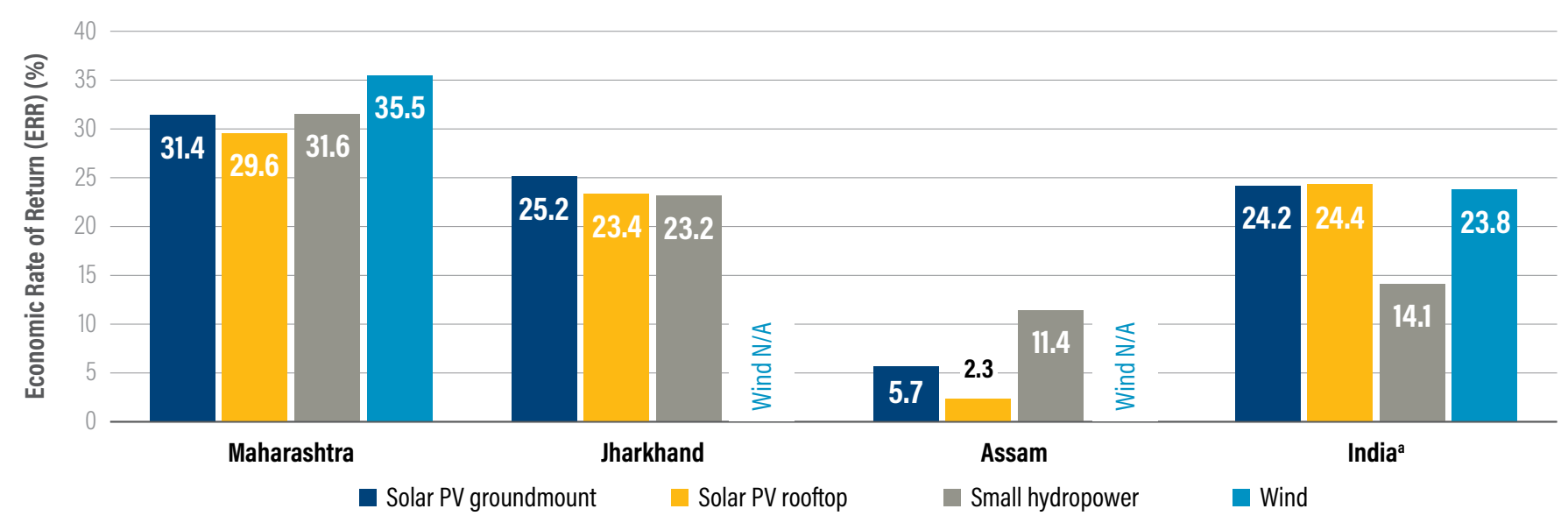

Notes: $\mathrm{ERR}=$ economic rate of return; $\mathrm{NA}=$ not available; $\mathrm{PV}=$ photovoltaic; $\mathrm{RE}$ = renewable energy. a. Estimates from Hingne et al. (2020) updated for consistency with state-level calculations.

Source: WRI authors. 
can ensure that RE deployment is more socially and environmentally sustainable. Moreover, for states with a high RE potential but low levels of deployment at present, such as Jharkhand and Assam, ERR estimates can make a clear case for financial or policy support for certain RE technologies, which will help enhance RE uptake.

\section{By providing insight into the drivers of socio- economic returns from RE deployment within a region, ERR estimates can help policymakers formulate better RE policies and make better implementation choices. For example, avoided water-use impact is the main driver of the returns from RE technology deployment in Maharashtra, which indicates the importance of ancillary policies, such as those addressing water use in electricity generation in the region. Similarly, the key role of avoided health impacts from air pollution in Jharkhand indicates the unsuitability of RE technologies that produce particulate emissions, such as biomass. In Assam, grid integration costs can negate the benefits from RE technologies such as solar PV, which indicates that decentralized RE solutions may be the way forward in the state.}

\section{Going forward, the results of this analysis can be improved by conducting subregional analyses for larger states and developing better datasets and methodologies. In large states such as Maha- rashtra, there is considerable subregional variability in environmental conditions such as water availability or wind speeds, which are higher in coastal and hilly regions, indicating that subregional or project-specific ERR analyses may be warranted. Furthermore, the development of better datasets and valuation metrics can help improve such analyses by allowing a larger range of impacts to be included in the quantitative estimates, such as those on jobs and livelihoods, and by capturing the distributional implications of impacts across different population subgroups, such as those by income or gender, within states.}

\section{INTRODUCTION}

Reliable, affordable, and sustainable energy is an important prerequisite for meeting our economic, developmental, and climate goals. If global climate change and its impacts are to be minimized, renewable electricity must form the core of the energy system across all major sectors including industry, transport, and buildings (IEA 2021). According to IEA, if the world has to reach net-zero emissions by 2050, renewables have to constitute almost 90 percent of the electricity mix by 2050 (IEA 2021). Globally, renewables have been consistently outcompeting fossil fuels both in costs and the rate of growth, which has doubled over the past decade. In fact, despite the health and economic crisis brought about by COVID-19, renewables grew by 45 percent globally (IEA 2020 ) in 2020. This growth is higher than the annual average over the past decade.

Renewables also form an integral part of India's climate and developmental priorities. Along with its Nationally Determined Contribution (NDC) commitment under the Paris Agreement to increase the share of installed non-fossil power to 40 percent by 2030, India has also set a domestic target of $175 \mathrm{GW}$ of renewable capacity by 2022 and recently announced the intention to scale nonfossil capacity to 500 GW by 2030 (PIB 2021; UNFCCC 2015). Between 2016 and 2020, renewable installation in India has grown by a compound annual growth rate of 17.33 percent (MNRE(a) n.d.), and this is expected to grow further with the new targets and decreasing costs. India is also exploring newer RE technologies such as hydrogen, floating solar, off-shore wind, and geothermal power (MNRE(b) n.d.). However, although these new technologies will become commercially viable in the future, prominent technologies such as wind, solar, and small hydro power (SHP) will continue to grow, thus reshaping India's power mix, which is currently dominated by fossil fuels, particularly coal.

As India negotiates this energy transition, renewables can offer a host of co-benefits. Power generation from renewables can improve health outcomes compared to fossil fuel combustion, by reducing the exposure of populations to particulate matter emissions, improving water availability due to lower withdrawals and consumption for power generation, and lowering climate impacts from avoided greenhouse gas (GHG) emissions (Hingne et al. 2020). At the same time, they can entail costs due to increased land use that may displace agriculture or forest land, displace jobs, or have ecological impacts, such as disruptions to river systems by hydropower (CPR 2018). Such costs need to be minimized to make the deployment of renewables optimal and sustainable. If considered at the outset and managed adequately during the implementation, renewable power deployment can help meet India's economic and sustainable development (SD) goals.

\subsection{Framework for Assessing SD Impacts of Renewable Power Technologies}

WRI's Framework for Assessing Sustainable Development Impacts of Renewable Power Technologies (henceforth called the SD Framework; Hingne et al. [2020]) offers an economic approach to considering and combining relevant costs and benefits from renewable 

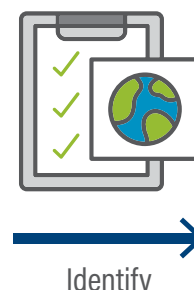

objectives of

assessing SD

impacts of

renewable

energy (RE)

technologies
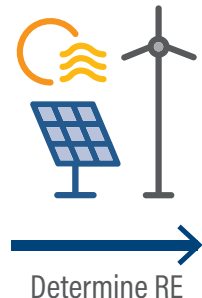

technologies

to be assessed

and the

baseline

technology

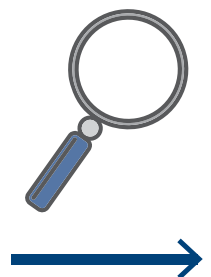

Identify

relevant impact

categories and

indicators
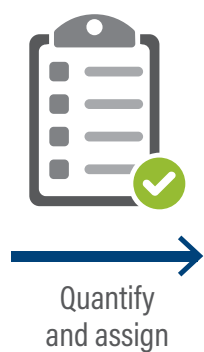

economic value

to SD impacts

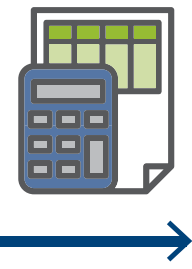

Calculate

the economic rate of return (ERR) of RE technologies
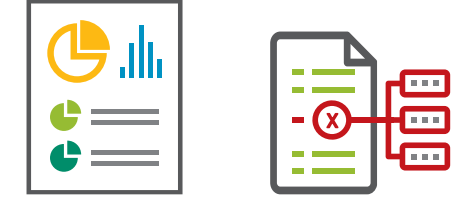

Report SD

impacts not

included in

estimation

of ERR

Notes: $\mathrm{RE}=$ renewable energy; $\mathrm{SD}=$ sustainable development.

Source: Hingne et al. 2020.

power deployment into a convenient metric, namely, the economic rate of return (ERR), to support decisionmaking. The SD Framework is a stepwise approach (see Figure 1) that can be applied to any technology of choice, at the national, state, or local level, to identify and estimate the impacts of deployment. The SD Framework helps policymakers, investors, and project proponents gain insight into the drivers of economic costs and returns to society from RE deployment within a specific context, which can inform planning and decision-making to make RE deployment more environmentally and socially sustainable. Although the framework also allows for the assessment of impacts beyond deployment, this depends on the availability of data and methodologies to assign economic values to relevant lifecycle impacts. Therefore, results must be interpreted in light of the limitations of the assessment carried out in a particular case and the impacts beyond those included in the assessment boundary (e.g., upstream/downstream impacts), where possible.

When applied at the regional level, it provides better insights as to which technologies are beneficial to local communities and must be prioritized by policymakers. In this paper, we apply the SD Framework to assess the impacts of renewable technology deployment in three Indian states: Maharashtra, Jharkhand, and Assam. In the following sections, we outline how the SD Framework is applied, including the selection of states, relevant RE technologies, quantification impacts, and its limitations. We then discuss the estimated impacts and economic returns and compare them across technologies and states, and with national estimates from Hingne et al. (2020). Finally, we discuss the insights and implications of our assessment for decision-making.

\subsection{Use of ERR as a Decision-Making Tool}

The ERR is a comparative summary statistic, synthesizing the market as well as non-market costs and benefits associated with RE technology deployment into a single metric, which when considered along with other relevant decision-making parameters, such as nonmonetizable project impacts, can aid policymakers in comprehensive decision-making. The ERR may be used for the following:

Compare socioeconomic returns across different RE technologies: This enables the selection of technologies with higher societal benefits in a particular geography or context.

Define an acceptance criterion for a project: An ERR greater than the social discount rate (SDR)-the hurdle rate for public investments in welfare-implies the project provides acceptable levels of socioeconomic benefits to society and should be undertaken.

\section{- Select technologies that require policy sup-} port: An internal rate of return (IRR) greater than the market benchmark rate of return for a project indicates its financial viability from the point of view of a private investor. Although established $\mathrm{RE}$ technologies such as solar PV are financially viable, relatively new $R E$ technologies that fulfill the acceptance criterion (ERR > SDR) may not be financially viable in the market, in comparison with mature fossil fuel technologies. In such cases, public investment or policy support is justified. The difference between the market benchmark rate of return for investment and the project's IRR can help 
policymakers estimate the level of public investment or policy support required. This decision-making structure is summarized in Table 1.

\section{Include socioeconomic considerations in public-private investments: Assessment of} socioeconomic impacts and the ERR may support the selection of bidders for public-private projects. Along with technical and financial criteria, private entities can be mandated to include an assessment of the potential impacts of their proposed plan and include specific measures to enhance ERR by improving the environmental and social performance of deployment. This additional consideration can be included in the selection criteria of winning bids to ensure that the deployment of RE will be sustainable and benefit society.

\section{ASSESSMENT METHODOLOGY}

\subsection{Step 1: Define the Objectives of SD Impact Assessment}

This study applies the SD Framework to understand how the economic returns for RE technologies vary at the regional level, and how this variation relates to or can inform RE deployment in different states. In India, the rise in RE deployment has been driven primarily by a few states such as Tamil Nadu, Karnataka, Gujarat, Maharashtra, Rajasthan, Telangana, Andhra Pradesh, and Madhya Pradesh. At the same time, some states with relatively high RE potential, such as Jharkhand, Assam, Orissa, Bihar, and Chhattisgarh, have not achieved more than 4 percent of their estimated RE potential (MNRE 2019; NITI Aayog 2015).

Although factors such as favorable regulatory policy, land availability, capital, and so on, play an important role in RE deployment, an assessment of the SD impacts and economic returns of RE technologies can help identify whether a case can be made for supporting the deployment of certain RE technologies in such
Table 1 | Using ERR in Decision-Making

\begin{tabular}{|llll|}
\hline $\begin{array}{l}\text { ECONOMIC } \\
\text { VIABILITY }\end{array}$ & $\begin{array}{c}\text { PUBLIC } \\
\text { INVESTMENT } \\
\text { JUSTIFIED }\end{array}$ & \multicolumn{1}{c|}{$\begin{array}{c}\text { FINANCIAL } \\
\text { VIABILITY }\end{array}$} & $\begin{array}{c}\text { POLICY } \\
\text { SUPPORT } \\
\text { NEEDED }\end{array}$ \\
\hline$E R R>S D R$ & Yes & $\begin{array}{l}\text { IRR }>\text { market } \\
\text { benchmark rate } \\
\text { of return }\end{array}$ & No \\
\hline$E R R>S D R$ & Yes & $\begin{array}{l}\text { IRR }<\text { market } \\
\text { benchmark rate } \\
\text { of return }\end{array}$ & Yes \\
\hline$E R R<S D R$ & No & NA & NA \\
\hline
\end{tabular}

Notes: $\mathrm{ERR}=$ economic rate of return; IRR = internal rate of return; $\mathrm{NA}=$ not applicable. Sources: MNRE(a) n.d.; Hingne et al. 2020.

states. For a high-deployment state, the assessment can throw light on how such economic returns explain the observed regional deployment.

Accordingly, we apply the following selection process:

1. We select the top 15 states by RE potential.

2. We then select one state with high RE potential and high deployment.

3. We select two states with high RE potential but low deployment.

Among the states with high RE deployment, we select Maharashtra due to the ease of access to stakeholders in the local government for consultations. Among states with high potential and low deployment, we select Jharkhand and Assam as they have one of the lowest RE penetration rates in the country, despite featuring among the top 15 states by RE potential. In addition to the RE potential and penetration (see Table 2), these states also offer diversity in their geographic conditions and economic development, which is useful for highlighting the context-specific application and results of the SD Framework.

Table 2 | Summary of RE Deployment in Maharashtra, Jharkhand, and Assam

\begin{tabular}{|lccccc|}
\hline STATE & $\begin{array}{l}\text { INSTALLED RE } \\
\text { CAPACITY 2019 } \\
\text { (MW) }\end{array}$ & $\begin{array}{l}\text { INSTALLED } \\
\text { CONVENTIONAL } \\
\text { CAPACITY 2019 (MW) }\end{array}$ & $\begin{array}{l}\text { OVERALL RE } \\
\text { POTENTIAL } \\
\text { (MW) }\end{array}$ & $\begin{array}{l}\text { RE DEPLOYMENT } \\
\text { RELATIVE TO OVERALL } \\
\text { RE POTENTIAL (\%) }\end{array}$ & $\begin{array}{l}\text { PER CAPITA INCOME } \\
\text { (INR) (IN CONSTANT } \\
\text { 2011-2012 PRICES) }\end{array}$ \\
\hline Maharashtra & 9,710 & 29,746 & 77,830 & 12.5 & 147,450 \\
\hline Jharkhand & 47 & 2,276 & 18,500 & 0.3 & 54,982 \\
\hline Assam & 75 & 1,191 & 14,270 & 0.5 & 60,695 \\
\hline
\end{tabular}

Notes: $\mathrm{MW}=$ megawatt; $\mathrm{RE}=$ renewable energy.

Source: MNRE 2019; NITI Aayog 2015. 


\subsection{Step 2: Determine the RE Technology to Be Assessed and the Baseline Technology}

In this step, we select the RE technologies to be assessed and the baseline technology, defined as the technology most likely to be installed in the absence of RE investment, for each state.

Although all hydropower in India is now considered as RE (PIB 2019), we include only SHP ( $<25$ megawatt [MW]) among the RE technologies considered for this analysis. This is because larger hydropower projects can cause significant ecological and social impacts due to events such as building a reservoir, river diversion, displacement of the local population, or change in land use, which may not be captured in our assessment without site-specific data.

\section{Step 2.1: Selection of RE Technologies}

The selection of RE technologies for assessment in each state is based on their estimated potential, prominence in policy targets, current prevalence, and stakeholder consultations.

\section{Potential of RE technology and prominence} in policy targets: As seen in Table 3 , the potential of RE technologies and their prominence in policy targets are correlated. Solar PV (in this study, the term implies grid-connected, ground-mounted, and rooftop solar $P V$ technology, unless otherwise specified) has the highest potential and the highest installation target in the three states, followed by SHP for Jharkhand and Assam. Wind energy has high potential and features in policy targets for Maharashtra but not for Jharkhand and Assam.

Table 3 | RE Potential and Targets for Maharashtra, Jharkhand, and Assam

\begin{tabular}{|c|c|c|c|c|c|}
\hline & & POTENTIAL (MW) & $\begin{array}{l}\text { MNRE TARGET } \\
\text { (MW) }\end{array}$ & $\begin{array}{l}\text { INSTALLED CAPACITY } \\
\text { (MW) AS OF } 2020\end{array}$ & $\begin{array}{l}\text { POLICY PRIORITY } \\
\text { (YES/NO) }\end{array}$ \\
\hline \multirow[t]{5}{*}{ Maharashtra } & Solar PV & 64,320 & 11,926 & 2,293 & Yes \\
\hline & Wind & 9,400 & 7,600 & 5,010 & Yes \\
\hline & SHP & 786 & 50 & 379 & Yes \\
\hline & Bagasse/Biomass & 2,981 & 2,469 & 2,568 & No \\
\hline & Waste to Energy & 287 & 0 & 12 & No \\
\hline \multirow[t]{5}{*}{ Jharkhand } & Solar PV & 18,180 & 1,995 & 52.06 & Yes \\
\hline & Wind & 112 & 0 & 0 & No \\
\hline & SHP & 228 & 10 & 4.05 & Yes \\
\hline & Bagasse/Biomass & 90 & 0 & 4.3 & No \\
\hline & Waste to Energy & 10 & 0 & 0 & No \\
\hline \multirow[t]{5}{*}{ Assam } & Solar PV & 13,760 & 664 & 59.15 & Yes \\
\hline & Wind & 112 & 0 & - & No \\
\hline & SHP & 202 & 25 & 34.11 & Yes \\
\hline & Bagasse/Biomass & 212 & 0 & - & No \\
\hline & Waste to Energy & 8 & 0 & 2 & No \\
\hline
\end{tabular}

Notes: MNRE = Ministry of New and Renewable Energy; PV = photovoltaic; $\mathrm{SHP}=$ small hydro power. Sources: MoSPI 2020; NITI Aayog 2015. 


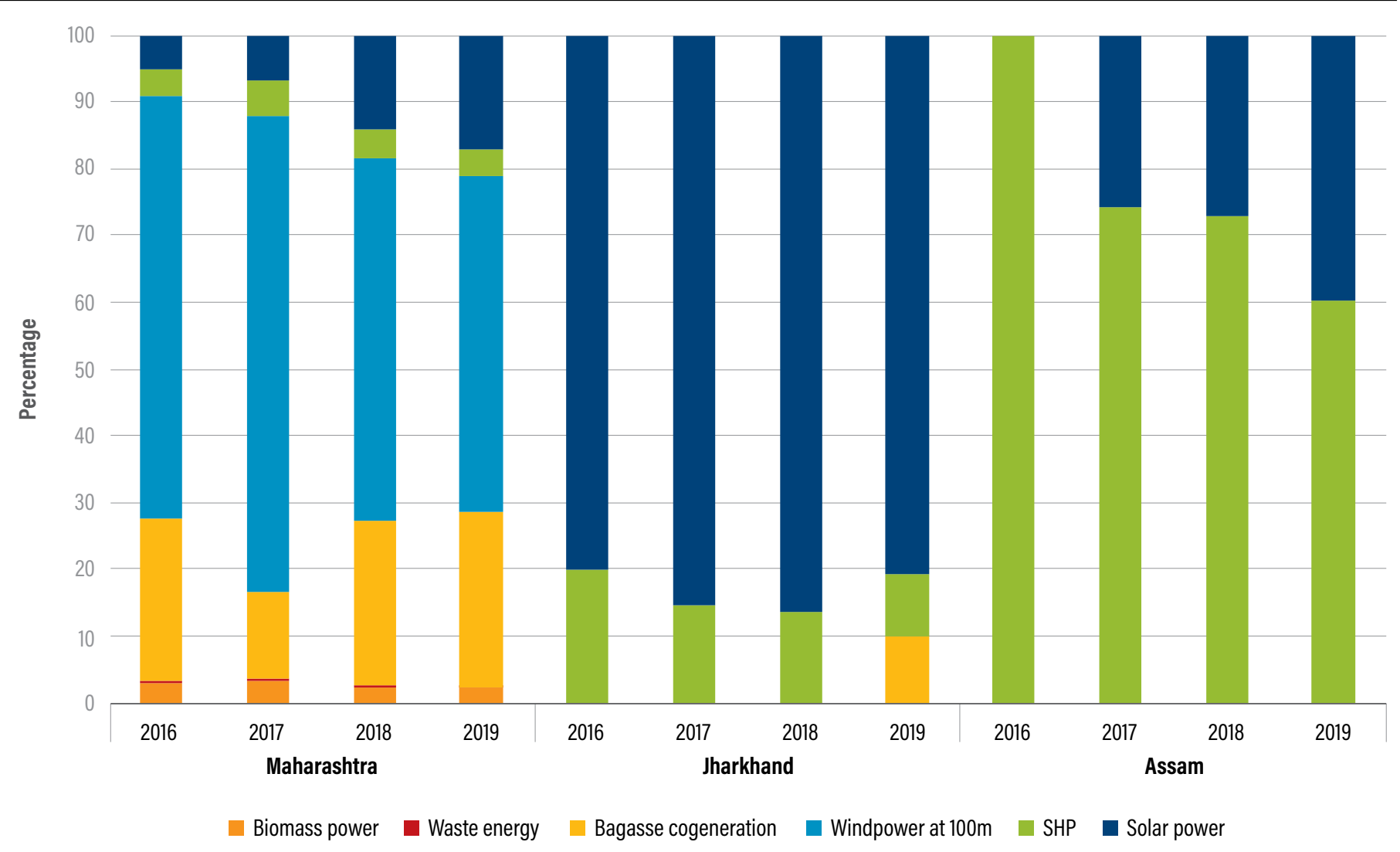

Notes: $\mathrm{RE}=$ renewable energy; $\mathrm{SHP}=$ small hydro power.

Sources: MoSPI 2018, 2019, 2020.

- Current Prevalence: Historically, a combination of solar PV and SHP has contributed to the RE power mix in Assam and Jharkhand, with SHP dominating in Assam and solar PV dominating in Jharkhand. In Maharashtra, wind and bagasse cogeneration have been leading contributors to the RE mix (see Figure 2).

- Stakeholder Consultation: We selected the $\mathrm{RE}$ technologies for our assessment based on the criteria summarized in Table 3, and validated through stakeholder consultation, where possible. Representatives from Maharashtra's Department of Industries, Energy and Labor Department and the Jharkhand Renewable Energy Development Agency were consulted to understand the policy focus for different technologies. For the states of Assam and Jharkhand, solar PV and SHP are the dominant technologies in terms of potential, installed capacity, and policy priority and are therefore selected for our assessment. For Maharashtra, wind is also selected (and bagasse cogeneration eliminated) by applying the same criteria.

\section{Step 2.2: Selection of Baseline Scenario}

For the baseline scenario for Maharashtra and Jharkhand, we found that a coal-based supercritical thermal power plant is the most likely technology to meet the state's future electricity demand. Historically, in both states, coal-based power generation has dominated their power mix: 68 percent in Maharashtra and 90 percent in Jharkhand (CEA 2020c). Figure 3 illustrates the installed thermal power capacity in the three states. 


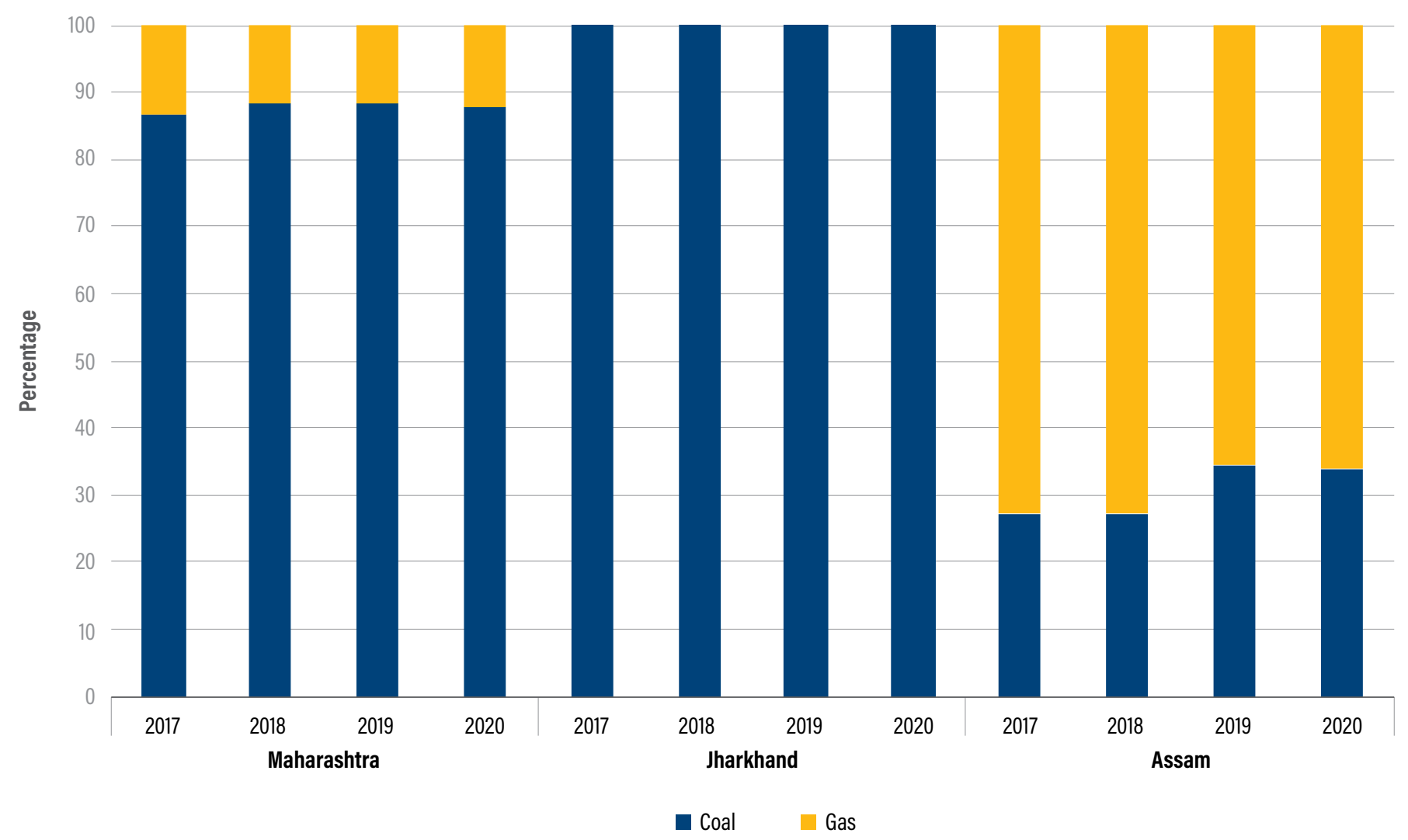

Source: CEA 2018a, 2019a, 2020c

In the case of Assam, recent capacity additions of coal-based power and a low CUF for gas plants due to shortage of gas have shifted the trend toward coal-based generation from gas-based generation. As of 2020, coal fulfills 60 percent (CEA 2020b) of the state's electricity demand. Therefore, we choose supercritical coal as the baseline for our primary analysis for Assam. However, we assess a gas baseline as an additional scenario due to its relatively large share in the installed capacity in Assam compared to other regions in India. Table 4 summarizes the RE technology and baseline technology selections for the three states.

\subsection{Step 3: Identify the Relevant SD Impact Categories and Indicators}

This step aims to identify the significant and relevant SD impact categories associated with the deployment of RE technology in the region and the corresponding indicators that are best suited for their assessment. Impact categories that are quantifiable and to which an economic value can be assigned are included in our assessment. Other impacts to which an economic value cannot be assigned should be qualitatively assessed and reported separately, when feasible and relevant. These
Table 4 | State-Wise RE Technology and Baseline Selection

\begin{tabular}{llll}
\hline STATE & ASSAM & JHARKHAND & MAHARASHTRA \\
\hline $\begin{array}{l}\text { Baseline } \\
\text { tech- } \\
\text { nology }\end{array}$ & Coal & Coal & Coal \\
\hline $\begin{array}{l}\text { RE tech- } \\
\text { nology }\end{array}$ & Solar PV & Solar PV & Solar PV \\
& SHP & SHP & SHP \\
& - & - & Wind \\
\hline
\end{tabular}

Notes: $\mathrm{PV}$ = photovoltaic (rooftop and ground mounted); RE = renewable energy; $\mathrm{SHP}=$ small hydro power.

Sources: WRI authors. 
qualitative assessments could also provide valuable insights for decision-making. This step involves two sub-steps:

Identify the impact categories to be included in the assessment.

- Identify the indicators for each impact category and determine if they are suitable for use in the ERR analysis for that state.

\section{Step 3.1: Identify Impact Categories to Be Included in the} Assessment

This sub-step helps clarify the SD impacts of RE technology across social, economic, and environmental dimensions. The selection of impact categories should be based on the following three criteria (Rich et al. 2018):
Relevance: The selected impact category should adequately represent the objectives of the assessment, national and state policy objectives, Sustainable Development Goals (SDGs), and stakeholder and local priorities.

- Significance: The selected impact category must be significantly impacted by the technology.

Comprehensiveness: The assessment should consider both negative and positive SD impacts as well as impacts across each of the three dimensions (social, economic, and environmental).

Hingne et al. (2020) apply these three criteria to identify seven relevant impact categories of RE deployment for India and examine the interlinkages and causal links between the identified impact categories and the SDGs, which are summarized in Table 5 . We consider the same impact categories for our state-level assessment since no additional impacts were found to meet the above criteria.

\section{Table 5 | Impact Categories with Causal Links to Potential Impacts and Policy Goals}

IMPACT CATEGORY

Health impacts$$
\text { ( }
$$

\section{Water impacts}

Land impacts

than fossil-fuel-based power plants and may affect agricul-
due to agricultural and forest land diversions, respectively,
toward these projects. These can impact agricultural
income, biodiversity, ecosystem services, and carbon
sequestration potential.

Climate change impacts

\section{CAUSAL LINK OF POTENTIAL IMPACTS}

Fossil fuel power generation results in emissions of particulate matter (PM), sulfur oxides ( $\mathrm{SO}_{\mathrm{x}}$ ), and nitrogen oxides (NO) ${ }_{x}$, which adversely impact human health. RE technology can mitigate this impact by reducing/avoiding these pollutant emissions compared to fossil fuel emissions.

\section{RE deployment should help achieve targets relating to} water access, scarcity, and management since RE technologies, in general, consume less water than fossil-fuel-based power plants. However, deploying RE that requires water for its operations could aggravate water scarcity in already water-stressed regions.

Large-scale RE projects are, in general, more land intensive than fossil-fuel-based power plants and may affect agricultural production and income and/or increase deforestation sequestration potential

$\mathrm{RE}$ deployment reduces carbon dioxide $\left(\mathrm{CO}_{2}\right)$ emissions by substituting fossil-fuel-based energy generation, consequently helping mitigate global climate change and its negative impacts such as increased ocean acidification and poverty-inducing extreme events.
RELEVANT POLICY PRIORITY/SDG GOAL

SDG 3-Good health and well-being: Reduce illness and premature death from exposure to pollutants.

SDG 6-Clean water and sanitation: Improve availability of water, including for drinking and sanitation.

SDG 2-Zero hunger: Improve food security.

SDG 15-Life on land: Protect biodiversity and ecosystem services.

India NDC target: Create 2.5 to 3 gigatons of additional carbon sink through forest cover by 2030.

SDG 13: Climate action.

SDG 14: Life below water.

SDG 1: No poverty.

India's NDC targets for RE are discussed in Section 1. 


\section{IMPACT CATEGORY}

Employment impacts

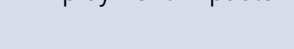

列

Energy security

\section{CAUSAL LINK OF POTENTIAL IMPACTS}

The net employment effects of RE deployment depend on a variety of factors, such as the RE technology supply chain (with diverse skill requirements), level of automation adopted, skill sets of displaced workers, and the effects of macroeconomic feedback loops. Further, local-level distributional effects may vary widely. There is some evidence that the RE sector improves outcomes in women's agency and employment compared to conventional energy. However, this cannot be assumed by default as women still encounter barriers to entry without supporting policies (see Box 1). ${ }^{a}$

\section{Shifts toward RE technologies would help reduce de- pendencies on imports of conventional fuels while also diversifying the energy mix. However, in the absence of supporting policies, this can create import dependencies for RE technology components. For example, $90 \%$ of solar modules used in India are currently imported, something the government is actively attempting to address through policies to promote domestic manufacturing. ${ }^{b}$}

\section{RELEVANT POLICY PRIORITY/SDG GOAL}

SDG 8: Promote inclusive and sustainable economic growth, employment, and decent work for all.

SDG 5: Gender equality and women's empowerment.

Notes: $\mathrm{NDC}=$ Nationally Determined Contribution; $\mathrm{RE}$ = renewable energy; $\mathrm{SDG}=$ Sustainable Development Goals

Sources:

a. Jairaj et al. 2017.

b. ORF 2020.

Adapted from Hingne et al. 2020.

\section{Box 1 | Employment Impacts of RE Technologies}

Renewable energy (RE) technologies vary widely in the employment opportunities they generate. India-specific employment coefficients (over the entire technology value chain) indicate that rooftop solar PV creates the maximum opportunities at approximately 25 full-timeequivalent (FTE) jobs per MW per year, followed by small hydro power (SHP) (14 FTE jobs/MW/year) and ground-mounted solar PV and wind, which generate fewer than 5 FTE jobs/MW/year, and are comparable to coal and gas technologies in this respect. ${ }^{a}$

However, realization of the benefits of such employment opportunities depends on a variety of factors. One such factor is the availability of reskilling opportunities for displaced workers, which is especially relevant in the case of states such as Jharkhand, which has one of the highest proportions of coal-based jobs among Indian states. ${ }^{b}$ Another factor is enabling access to these jobs for women, who are grossly underrepresented in the workforce, with workforce participation rates of all three states comparable to the national average of 25.5 for females versus 53.2 for males.

\section{Sources:}

a. CEEW and SCGJ 2019.

b. Bhushan et al. 2020.

c. MoSPI 2014

\section{Step 3.2: Identify Indicators for Each Impact Category} and Determine Their Suitability for ERR Analysis

This step identifies the appropriate indicators used to quantify the selected impact categories and assess their suitability for economic analysis. Although the indicators should be based on the objectives outlined in Step 1 and data availability, they should also help users evaluate how RE technologies influence each impact category.

Assigning an economic value to the indicators is possible if the following criteria are met:

\section{A robust methodology to quantify the impacts is available.}

- A robust methodology to assign an economic value to the indicators is available.

- The most recent and accurate data needed for quantification and valuation are available.

Table 6 (column B) lists the indicators used to quantify each impact category considered in this study. 


\subsection{Step 4: Quantify and Assign an Economic Value to SD Impacts}

This step quantifies the impact indicators identified in the previous step and assigns an economic value to each indicator. The sub-steps specified by Rich et al. (2018) have been used to quantify the indicators identified in Step 3. The sub-steps for each indicator include the following:

Defining the assessment boundary and period.

- Choosing the assessment method.

Estimating the net impact for each indicator.

Estimating the net economic value for each indicator.

\section{Step 4.1: Define the Assessment Period and Boundary}

The assessment period is the period over which the impacts are evaluated. We use 25 years (CERC 2018a), the useful life of RE technology power plants, as the assessment period for each of the indicators considered.

The assessment boundary determines the scope of the assessment. RE technology may entail environmental impacts due to upstream activities such as extraction and mining of materials; emissions associated with transport of equipment, which may be imported from outside the country; fragmentation of habitat and disruption in free movement or migratory patterns of local fauna; and downstream activities, such as disposal of waste after decommissioning (Hernandez et al. 2014; Mortensen 2013; Tawalbeh et al. 2021). Moreover, displacement of conventional technologies, for example, coal, by RE may also be accompanied by social impacts on local communities and governments due to loss of employment in associated activities, for example, mining, and in tax revenues from coal production (Gawande and Chaudhry 2019). A lifecycle assessment allows for impact analysis across the value chain of technologies and should ideally be included while estimating the ERR (for both the RE technology and the baseline technology under consideration).

For this study, however, only the impacts in the generation phase of technology deployment are considered. Upstream and downstream impacts are excluded since their assessment requires detailed, location-specific data on operational parameters across the value chain of each technology under consideration, making them difficult to include in an ex-ante assessment.

\section{Step 4.2: Choosing the Assessment Method}

The SD Framework refers to three assessment methods for each indicator:
Scenario method: Compare two scenarios, the baseline scenario and the technology scenario, defined and estimated for the same region.

- Deemed Estimates method: Estimate the net change resulting from the deployment of RE technology, relative to the baseline, within a single scenario. The results obtained are similar to the scenario method, except that the baseline and technology scenarios are not defined and are calculated separately.

- Comparison method: Compare one region affected by the technology with an equivalent region that is not affected by the technology.

To estimate the ex-ante ERR, the Deemed Estimates or Scenario methods may be used, with both giving similar results. We use the Deemed Estimates method in our study due to the relative convenience of assessing net costs and benefits within a single scenario. In addition, the Comparison method requires the identification of comparable regions, which is typically difficult, given the context-specific nature of the impacts.

\section{Step 4.3: Estimate the Net Impact for Each Indicator}

We calculate the net impact for each indicator as the difference between the estimated value of the impact indicator for the RE technology and that for the baseline technology, using the Deemed Estimates method. These impacts are measured per megawatt of installed RE capacity (see Box 2). Table 6 (Column C) summarizes the methods used to quantify the net impacts for each indicator.

\section{Box 2 | Estimating Net Impacts}

The baseline scenario represents the scenario in which the power generated by $1 \mathrm{MW}$ of installed RE technology capacity is substituted by an equivalent generation from the baseline technology, in our case supercritical coal. To account for the difference in the capacity utilization factor (CUF) of RE technology and coal technology, the installed capacity required in the baseline scenario is approximated by scaling the installed RE capacity by the ratio of the CUF of the RE technology to that of the coal-based technology.

It is important to take this into account to avoid overestimating net impacts for indicators. For example, we would estimate the net land use in a wind scenario relative to a coal baseline as Net Land Use $=$ Land use per MW $W_{\text {Wind }}-$ Land use per MW ${ }_{\text {coal }} \times \frac{\text { CUF }_{\text {Wind }}}{\text { CUF }_{\text {coal }}}$

Sources: WRI authors 
Step 4.4: Estimate the Net Economic Value for the Indicators

This sub-step assigns an economic value to the impact indicators. Assigning economic values to non-market impacts can employ different approaches, such as estimating the opportunity costs of an intervention or stakeholders' willingness to pay to create favorable conditions or eliminate unfavorable ones. The choice of method is usually informed by the objective of the assessment and the availability of data or methods to apply the chosen approach in the given context. As highlighted in the SD Framework, the assessment ensures that the impacts' aggregated valuation is not double counted. For example, any climate-related health risk is considered under the social cost of carbon (SCC), and mortality and morbidity outcomes are solely associated with exposure to non-GHG pollutant emissions.

Table 6 (column D) summarizes the valuation methods associated with the impact indicators used for our study's purpose. All monetary values are converted to 2017 price levels for the purpose of our calculations. The full methodology and assumptions used to quantify the impact for each impact category are available in Appendices A (health), B (water), C (land), and D (climate).

Table 6 | Quantification and Assignment of Economic Values to Chosen Impact Indicators

\begin{tabular}{|c|c|c|c|}
\hline A & B & C & D \\
\hline $\begin{array}{l}\text { IMPACT } \\
\text { CATEGORY }\end{array}$ & INDICATOR & QUANTIFICATION OF INDICATOR & $\begin{array}{l}\text { CHOSEN PARAMETER TO ASSIGN ECONOMIC } \\
\text { VALUE TO IMPACT }\end{array}$ \\
\hline \multirow[t]{3}{*}{ Health } & Mortality & $\begin{array}{l}\text { Net incidences of premature mortality due } \\
\text { to exposure to } \mathrm{SO}_{\mathrm{x}^{\prime}} \mathrm{NO}_{\mathrm{x}^{\prime}} \text { and } \mathrm{PM}_{2.5^{\prime}} \text { Calculated } \\
\text { based on the concentration-response functions } \\
\text { given by Walvekar et al. (2019) and Apte et al. } \\
\text { (2015) using a representative power plant and } \\
\text { population data at the state level. }\end{array}$ & $\begin{array}{l}\text { The value of statistical life (VSL) calculated for } \\
\text { India based on the human capital approach by } \\
\text { OECD (2012). }\end{array}$ \\
\hline & \multirow[t]{2}{*}{ Morbidity } & \multirow{2}{*}{$\begin{array}{l}\text { Net incidences of work-loss days (WLDs) and } \\
\text { respiratory hospital admissions (RHAs) due } \\
\text { to exposure to } \mathrm{SO}_{\mathrm{x}^{\mathrm{\prime}}} \mathrm{NO}_{\mathrm{x}^{\prime}} \text { and } \mathrm{PM} \mathrm{2.5}^{\prime} \text { Calculated } \\
\text { based on the approach by Gunatilakeet al. } \\
\text { (2014), using a representative power plant and } \\
\text { population data at the state level. }\end{array}$} & $\begin{array}{l}\text { WLD: The national minimum daily wage for an } \\
\text { unskilled worker in India defined by the Minis- } \\
\text { try of Labour and Employment (MoEL 2017). }\end{array}$ \\
\hline & & & $\begin{array}{l}\text { RHA: The average cost of a hospitalization } \\
\text { incident specific to each state (MoHFW 2014). }\end{array}$ \\
\hline Water & Water consumption & $\begin{array}{l}\text { Net quantity of water use calculated based } \\
\text { on estimates of water intensity of power } \\
\text { generation for different technologies in India } \\
\text { by Chaturvedi et al. (2017) and IRENA and WRI } \\
\text { (2018). }\end{array}$ & 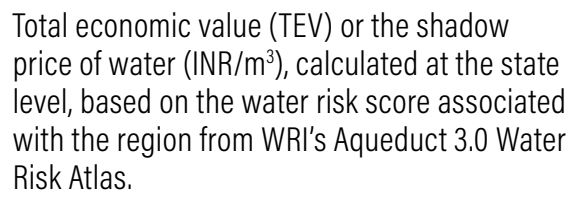 \\
\hline \multirow[t]{3}{*}{ Land } & \multirow[t]{3}{*}{$\begin{array}{l}\text { Area of land diverted } \\
\text { of a particular type } \\
\text { (agricultural, forest, or } \\
\text { barren) }\end{array}$} & \multirow{3}{*}{$\begin{array}{l}\text { Net land diverted for each land type consid- } \\
\text { ered, i.e., agricultural, forest, and wasteland. } \\
\text { The total land diversion is based on land-use } \\
\text { estimates for different technologies from Kumar } \\
\text { and Thapar (2017) and Gulati and Kacker (2016). } \\
\text { This is then apportioned between the three } \\
\text { land types, based on existing land-use pat- } \\
\text { terns in each state for the deployment of that } \\
\text { technology. }\end{array}$} & $\begin{array}{l}\text { Agricultural land: The opportunity cost of } \\
\text { agricultural income lost due to land diver- } \\
\text { sion, calculated at the state level based on } \\
\text { the weighted average of adjusted productiv- } \\
\text { ity (INR per hectare) for each crop grown in } \\
\text { the state using data from the Directorate of } \\
\text { Economics and Statistics (EANDS n.d.). }\end{array}$ \\
\hline & & & $\begin{array}{l}\text { Forest land: Net present value (NPV) of loss } \\
\text { of ecosystem services, carbon sequestration, } \\
\text { biodiversity losses of diverted forest land (INR } \\
\text { per hectare) based on the approach of (Verma } \\
\text { et al. 2014), calculated at the state level. }\end{array}$ \\
\hline & & & $\begin{array}{l}\text { Barren land: Economic value of diverting } \\
\text { barren land is assumed to be zero. }\end{array}$ \\
\hline $\begin{array}{l}\text { Climate } \\
\text { Change }\end{array}$ & $\begin{array}{l}\text { Greenhouse gas } \\
\text { emissions }\end{array}$ & $\begin{array}{l}\text { Net } \mathrm{CO}_{2} \text { emissions calculated using a genera- } \\
\text { tion-weighted emission factor for each state } \\
\text { based on data from CEA (2019a). }\end{array}$ & $\begin{array}{l}\text { Social cost of carbon (SCC) for India, as } \\
\text { calculated based on Nordhaus (2017). }\end{array}$ \\
\hline
\end{tabular}




\begin{tabular}{|c|c|c|}
\hline \multicolumn{3}{|r|}{ IMPACT CATEGORIES NOT INCLUDED IN THE STATE-LEVEL ASSESSMENT } \\
\hline $\begin{array}{l}\text { IMPACT } \\
\text { CATEGORY }\end{array}$ & POSSIBLE INDICATORS & RATIONALE \\
\hline $\begin{array}{l}\text { Employment } \\
\text { impacts }\end{array}$ & $\begin{array}{l}\text { - Number of jobs } \\
\text { created } \\
\text { - Quality of jobs } \\
\text { created } \\
\text { - Labor force partici- } \\
\text { pation of women }\end{array}$ & $\begin{array}{l}\text { The net effect of RE deployment on employment depends on a variety of factors (see Table 5), } \\
\text { making it difficult to quantify in the absence of reliable, disaggregated data on employment by } \\
\text { income, skills, and gender. }\end{array}$ \\
\hline $\begin{array}{l}\text { Energy } \\
\text { security }\end{array}$ & $\begin{array}{l}\text { - Availability } \\
\text { - Accessibility } \\
\text { - Affordability }\end{array}$ & $\begin{array}{l}\text { Energy security is highly context dependent, and the values of potential indicators in turn depend } \\
\text { on various factors, such as import dependence exposure level to external price and availability } \\
\text { shocks, and so on, making them difficult to quantify reliably. }\end{array}$ \\
\hline
\end{tabular}

Sources: WRI authors based on Hingne et al. 2020.

Table 7 | Economic NPV (in 2020) of Impact Categories per Megawatt of RE Technology Deployed

\begin{tabular}{|c|c|c|c|c|c|}
\hline \multirow[b]{2}{*}{ STATE } & \multirow[b]{2}{*}{ TECHNOLOGY } & \multicolumn{4}{|c|}{ ECONOMIC NPV (IN 2020) OF IMPACT CATEGORY PER MEGAWATT (MILLION 2017 INR) } \\
\hline & & HEALTH & WATER & CLIMATE & LAND \\
\hline \multirow[t]{4}{*}{ Maharashtra } & Solar PV ground mounted & 70.91 & 53.20 & 9.59 & -3.36 \\
\hline & Solar PV rooftop & 70.91 & 53.20 & 9.59 & 0.21 \\
\hline & Wind & 75.98 & 58.82 & 10.28 & -1.80 \\
\hline & SHP & 75.22 & 58.23 & 10.17 & $-1,10$ \\
\hline \multirow[t]{3}{*}{ Jharkhand } & Solar PV ground mounted & 86.17 & 13.53 & 6.84 & -1.36 \\
\hline & Solar PV rooftop & 86.17 & 13.53 & 6.84 & 0.19 \\
\hline & SHP & 121.87 & 19.74 & 9.68 & -0.26 \\
\hline \multirow[t]{3}{*}{ Assam } & Solar PV ground mounted & 33.00 & 3.48 & 7.15 & -0.79 \\
\hline & Solar PV rooftop & 33.00 & 3.48 & 7.15 & 0.11 \\
\hline & SHP & 66.50 & 7.32 & 14.50 & -2.93 \\
\hline
\end{tabular}

Notes: NPV = net present value; PV = photovoltaic; $R E=$ renewable energy; $S D R=$ social discount rate; $S H P=$ small hydro power.

The economic NPV of the impacts is calculated per megawatt of RE technology deployment over its lifetime of 25 years (relative to a coal baseline) using a discount rate of 8 percent, which is the SDR recommended for India by Murty et al. (2020) for time frames up to 30 years.

Sources: WRI authors.

The quantified values of the impact categories included in our assessment, that is, health, water, climate, and land, for the selected RE technologies in the three states are presented in Table 7. These represent the net present value (NPV) of the different impacts of the RE technology deployed (relative to the coal baseline) over the 25-year lifetime of the technology, and vary across the three states, depending upon local factors, which are discussed in Section 3. 


\subsection{Step 5: Calculate the ERR}

The ERR represents the rate of return to society associated with undertaking a project, in our case, RE technology deployment relative to a coal baseline, considering the economic costs and benefits over the project lifetime (see Box 3). In the ERR calculation, we consider the net impact for the impact categories included in the quantitative assessment using the valuation approaches in Table 6, along with traditional cashflows such as capital and O\&M costs for the technologies over a period of 25 years. We rely on normative average benchmarks specified by the respective State Electricity Regulatory Commissions for technology costs and operational parameters (see Appendix E).

In all the RE technologies assessed, we also include a grid integration cost of INR 1.5 per kilowatt-hour $(\mathrm{kWh})$ (CEA 2018b) since investment in the grid is required to effectively manage the intermittent nature of supply from renewables (OECD, IEA, and IRENA 2017).

We use the following IRR equation to arrive at the ERR (r) value:

$$
\sum_{y} \frac{\text { Net Cash Flow }_{y, t}}{\left(1+r_{t}\right)^{y}}=O
$$

where Net Cash Flow ${ }_{y, t}$ is the net economic value of the financial and economic benefits minus the costs in year $y$ for RE technology $t$ relative to the baseline, and $r$ is the economic rate of return.

\section{Box 3 | ERR and ENPV as Complementary Metrics}

The economic net present value (ENPV) is a metric that is closely related and complementary to the ERR and represents the difference between the discounted benefits and costs of a project at the social discount rate (SDR). A positive value of the ENPV implies a net benefit to society from the project.

The ERR is simply an estimate of the social discount rate at which the discounted costs are equal to the discounted benefits of the project; i.e., the ENPV is zero. Therefore, an ERR value greater than the SDR implies a positive ENPV, thereby indicating a net benefit to society from the project.

Furthermore, projects with an unconventional cash flow (more than one change in annual cash flow direction over the project lifetime) do not yield a unique ERR value. In such cases, where the ERR value is inconclusive, the ENPV may be used instead.

Note: ERR = economic rate of return.

Source: European Commission 2008.

\subsection{Step 6: Report the Assessment Results}

Table 8 summarizes the ERR values estimated for the states' selected RE technologies. In general, we found that Maharashtra has the highest rate of return to society for RE, followed by Jharkhand and then Assam. The estimated ERR for each of the RE technologies varied among the states, with wind seeing the highest rate of return in Maharashtra, solar PV in Jharkhand, and SHP in Assam. These results are discussed further in Section 3.

Table 8 | Estimated ERR for Selected RE Technologies for Each Region Assessed

\begin{tabular}{|c|c|c|c|c|}
\hline \multicolumn{5}{|c|}{ ESTIMATED ECONOMIC RATE OF RETURN (ERR) } \\
\hline TECHNOLOGY & MAHARASHTRA (\%) & JHARKHAND (\%) & ASSAM (\%) & INDIA (\%) \\
\hline Solar PV ground mounted & 31.41 & 25.16 & 5.67 & 24.20 \\
\hline Solar PV rooftop & 29.55 & 23.36 & 2.33 & 24.37 \\
\hline SHP & 31.57 & 23.17 & 11.45 & 14.14 \\
\hline Wind & 35.47 & NA & NA & 23.78 \\
\hline
\end{tabular}

Notes: $\mathrm{PV}=$ photovoltaic; $\mathrm{RE}=$ renewable energy; $\mathrm{SHP}=$ small hydro power.

a. National estimates from Hingne et al. (2020) updated for consistency with state-level calculations.

Source: WRI authors. 


\subsection{Limitations}

Ours is one of the first assessments that examines the economic returns of renewable technologies at the state level in India. However, these estimates are subject to limitations due to gaps in data, assessment methods, and the infeasibility of including all the relevant impact categories in the assessment. The limitations of our estimates are outlined below.

\subsubsection{Exclusion of Relevant Impact Categories}

Although we identify employment and energy security as relevant impact categories, we exclude them from the quantitative assessment due to the difficulty of quantifying the impacts (see Table 6). Other categories of impacts not quantified in our assessment are the ecological effects of SHP on river systems, which can often be significant (Anderson et al. 2015), and those of ash ponds, used for ash disposal in coal-based generation. These should be assessed separately or included in the assessment, wherever data are available.

\subsubsection{Exclusion of Systemic and Distributional Impacts}

An underlying assumption in quantifying costs and benefits for an individual project is that any impacts due to the project occur at the margin; in other words, the RE technology deployment under consideration does not significantly alter the overall system parameters (the economy, ecology, or grid). However, large projects, or the cumulative effect of several small projects, could lead to significant system-level impacts. For example, the impact on the local ecology due to the deployment of several SHP projects in a region might be greater than the sum of the impacts from individual projects. This is because the impact on habitats, flora and fauna, and sedimentation patterns does not change linearly with the scale or number of projects. Although we do not consider such systemic impacts in our analysis, they should be considered when using or interpreting our results.

Furthermore, our results represent average impacts per unit of RE technology deployment in a state, which can differ for different sub-regions across large states such as Maharashtra. Another aspect that our results do not consider is the distribution of different impacts, whether positive or negative, across different affected population subgroups. For example, water impacts, to the extent that they increase (or reduce) access to water for the local population, can create disproportionate benefits (or costs) for women, who typically spend significantly more time than men on average in collecting water for the household. Similarly, a change in the average level of air pollution can increase or reduce the time spent, primarily by women, in caring for the health of affected family members (UNDP 2020). Therefore, the distributive implications of impacts should also be considered along with our results, wherever relevant and feasible.

\subsubsection{Ex-ante Data-Dependent Assessment of Impacts}

Finally, our results provide only an ex-ante projection of the generation-phase impacts of RE technology deployment. Moreover, our results depend greatly on input data. Although we have used recent, state-specific data wherever available, parameters such as the relative costs of emerging RE technologies can change rapidly over time and should be updated before using the results. Similarly, when quantifying other impacts, we assume that the population distribution around new power plants will be the same as that around the existing power plants in the state (in the case of health impacts) and that the type of land used for technology deployment in the future will reflect the existing land-use patterns in the state (in the case of land impacts). These assumptions, too, may not hold over time, and may need to be updated.

Moreover, our results are also affected by estimates of the economic values of non-market indicators, which can vary significantly depending on the estimation methodology and assumptions. For example, although we conservatively use the Nordhaus (2017) estimate of the $\mathrm{SCC}$ for India to assign an economic value to $\mathrm{CO}_{2}$ emissions in our case study, Ricke et al. (2018) provide an SCC estimate for India that is 20 times higher. This value, if used, would more than double the economic returns for all RE technologies (see Appendix F), highlighting the need for careful attention to input parameters and assumptions while interpreting the results.

\section{RESULTS AND INSIGHTS}

\subsection{SD Impacts of RE for Maharashtra, Jharkhand, and Assam}

Here, we discuss the results of our assessment for Maharashtra, Jharkhand, and Assam, summarized in Figure 4. We also discuss the sensitivity of our primary results for each state, hereafter referred to as the Base Case, to variation in the values of key input parameters. A more comprehensive list of sensitivity scenarios is included in Appendix F. 


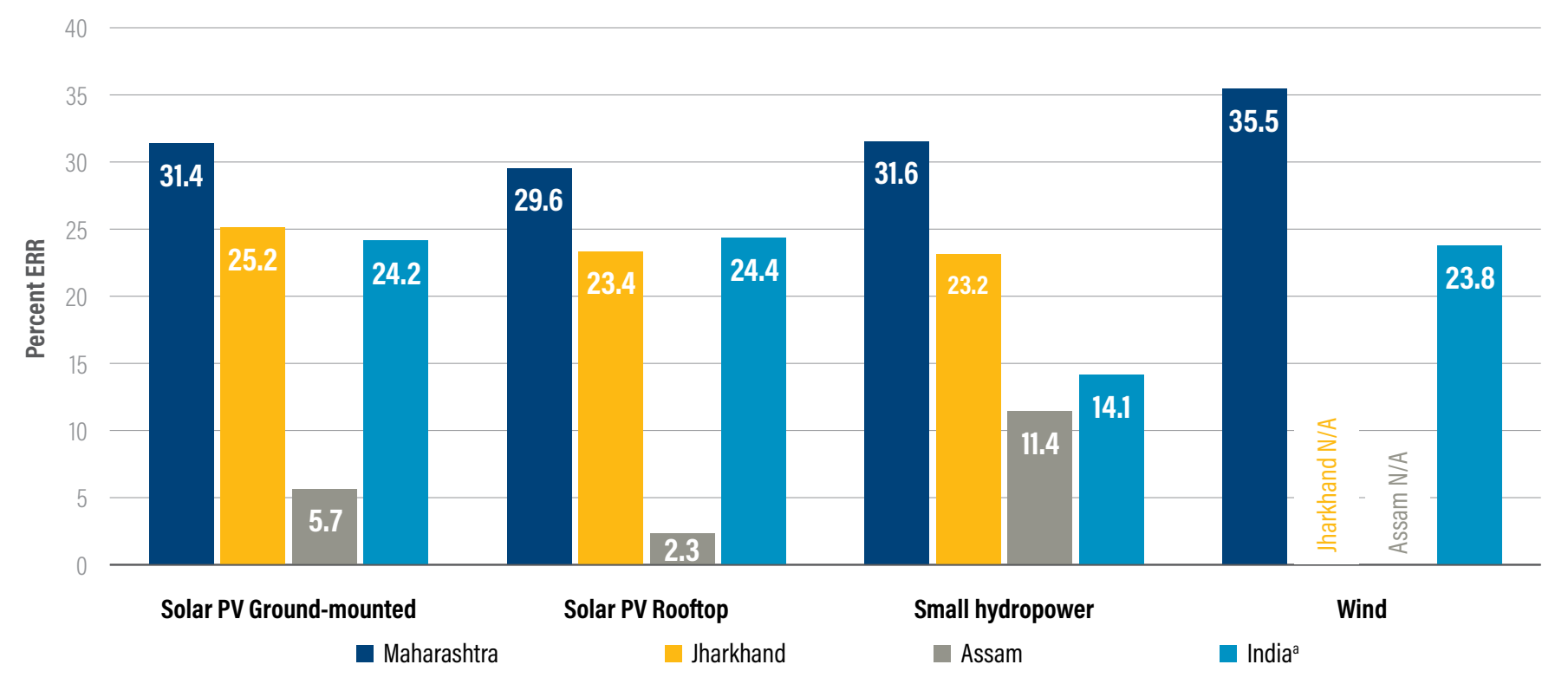

Notes: $\mathrm{ERR}=$ economic rate of return; $\mathrm{PV}=$ photovoltaic; $\mathrm{RE}$ = renewable energy. a. Estimates from Hingne et al. (2020) updated for consistency with state-level calculations. Source: WRI authors

Maharashtra: Our estimates indicate a relatively high rate of return from the deployment of all the RE technologies assessed for the state. These estimates are also the highest among the three states assessed. Among the different RE technology options assessed for Maharashtra, wind yields the highest return at 35.5 percent, followed by SHP (31.6 percent), solar PV ground mounted (31.4 percent), and solar PV rooftop (29.6 percent).

Avoided air pollution and reduced water use are the key drivers of the ERR of RE technologies in the state. Maharashtra sees the highest benefits from reduced water use due to $\mathrm{RE}$ deployment among the three states because the water scarcity in the state increases the economic value of water relative to that in the other states (see Table B3 in Appendix B). This is also why wind yields a higher rate of return than solar PV in the state, since solar PV panels require water for maintenance, resulting in lower avoided water-use benefits relative to the baseline compared to wind.

Another key driver of the high ERR value for wind and solar PV is the higher CUF norm for these technologies in the state compared to the benchmark values at the national level and in the other two states, which is influenced, in part, by local weather conditions and other factors such as grid management.
Across the three states and across all the RE technologies assessed (with the exception of rooftop solar PV), the net impact of RE deployment on land use is negative (see Table 7). Although this is partly because RE technologies, in general, are more land intensive than coal per unit of installed capacity, a critical factor that influences the magnitude of this impact is the type of land used for deployment. In Maharashtra, for example, if we alter the assumption about the type of land diverted for RE deployment in the Base Case (a combination of agricultural land, forest, and wasteland, based on the current and potential sites identified in the state) to only forest land diversion, our results change significantly, with rooftop solar PV yielding the highest returns after wind (see Table 9).

Finally, grid integration costs, although not significant relative to the magnitude of other impacts in the state at the assumed national average of INR $1.5 / \mathrm{kWh}$, are another important consideration in the context of Maharashtra. This is because the state has one of the highest rates of RE deployment relative to conventional power in the country at around 
35 percent, and studies suggest that although India's current RE targets are achievable with low to moderate integration costs, they increase significantly as the share of variable renewables in the electricity mix increases (Chaturvedi et al. 2018; Denholm at al. 2021; Palchak et al. 2017). The effect of higher grid integration costs on the ERR estimates is presented in Table 9. The effect of alternative values for other key input parameters on the results is also presented. For Maharashtra, these include the following:

A lower CUF for RE technologies, given that the specified CUF norms for the state are at the higher end of the national range. Furthermore, the relatively high level of existing RE penetration indicates the risk of potential curtailment with further deployment.

A lower intensity of water and coal consumption in the baseline scenario due to improvement in technology, which will reduce the water and health benefits, respectively, of RE technology deployment.

A potentially higher economic value of water due to an increase in water scarcity over time.

Jharkhand: Jharkhand also sees a relatively high rate of return from all of the selected RE technologies, with ground-mounted solar PV yielding the highest return at 25.2 percent, closely followed by rooftop solar PV (23.4 percent) and SHP (23.2 percent). The main reason for the slightly higher returns of solar PV is its lower capital costs relative to SHP, which can be expected to increase over time given the falling capital costs of solar PV.

The key driver of the returns associated with $\mathrm{RE}$ technology deployment in Jharkhand is the avoided health impacts (mortality and morbidity) from reduced air pollution, which were found to be the highest among the three states assessed (see Table 7). This is because of the greater population exposure to air pollution, which is attributable to a higher population density in Jharkhand relative to the other states assessed, and local environmental conditions, which determine the ambient concentration of air pollutants.

When compared to Maharashtra, Jharkhand sees a lower overall rate of return for all the RE technologies. The main reasons for this are the lower economic value of water in the state (because of the higher availability of water in the state), which significantly reduces the benefits of avoided water use from RE technology deployment. The climate benefits of avoided $\mathrm{CO}_{2}$ emissions are also lower, because the emission factor of the baseline technology in Jharkhand is lower. Moreover, in the case of solar, the scale of avoided impacts relative to the baseline per unit of deployment is further reduced due to the lower CUF norm in the state relative to that in Maharashtra.

Table 9 | Maharashtra: Results and Scenarios with Alternative Key Inputs

\begin{tabular}{|c|c|c|c|c|c|c|c|}
\hline & & ALTERI & IE RE TECHNOLO & ASSUMPTIONS & $\begin{array}{l}\text { ALTERNATI } \\
\text { TECHNOLOGY }\end{array}$ & $\begin{array}{l}\text { 3ASELINE } \\
\text { SUMPTIONS }\end{array}$ & $\begin{array}{l}\text { ALTERNATIVE } \\
\text { ECONOMIC } \\
\text { VALUES }\end{array}$ \\
\hline $\begin{array}{l}\text { RE } \\
\text { TECHNOLOGY }\end{array}$ & $\begin{array}{l}\text { BASE } \\
\text { CASE }\end{array}$ & $\begin{array}{l}\text { LOWER } \\
\text { CUF } \\
(-10 \%)\end{array}$ & $\begin{array}{l}\text { HIGHER GRID } \\
\text { INTEGRATION } \\
\text { COST }(+10 \%)\end{array}$ & $\begin{array}{l}\text { USE OF FOREST } \\
\text { LAND FOR } \\
\text { DEPLOYMENT }\end{array}$ & $\begin{array}{l}\text { LOWER } \\
\text { INTENSITY OF } \\
\text { WATER USE } \\
(-10 \%)\end{array}$ & $\begin{array}{l}\text { LOWER COAL } \\
\text { USE }(-10 \%)\end{array}$ & $\begin{array}{c}\text { HIGHER } \\
\text { ECONOMIC VALUE } \\
\text { OF WATER (+10\%) }\end{array}$ \\
\hline $\begin{array}{l}\text { Solar PV } \\
\text { ground } \\
\text { mounted (\%) }\end{array}$ & 31.41 & 25.08 & 30.22 & 28.54 & 29.70 & 29.25 & 34.91 \\
\hline $\begin{array}{l}\text { Solar PV } \\
\text { rooftop (\%) }\end{array}$ & 29.55 & 22.80 & 28.23 & 29.55 & 27.66 & 27.15 & 33.41 \\
\hline Wind (\%) & 35.47 & 28.36 & 34.21 & 32.58 & 33.65 & 33.17 & 39.29 \\
\hline SHP (\%) & 31.57 & 24.81 & 30.30 & 28.45 & 29.75 & 29.26 & 35.41 \\
\hline
\end{tabular}

Notes: $\mathrm{CUF}=$ capacity utilization factor; $\mathrm{PV}$ = photovoltaic; $\mathrm{RE}=$ renewable energy; $\mathrm{SHP}=$ small hydro power . Source: WRI authors. 
Table 10 depicts the effect of alternative assumptions for key ERR drivers for the state on the Base Case ERR results. We see a similar effect on the results as for Maharashtra under the assumption of forest land diversion for RE technology deployment, with rooftop solar PV emerging as the technology yielding the highest returns in this scenario. We also explore other scenarios in Table 10, including a reduction in future capital costs or an improved CUF for solar PV technology. Further, since health impacts are critical in the state, we examine the effect of two alternative assumptions in this context:

Reduced air pollution from reduced coal consumption in the baseline scenario, owing to potential improvements in the baseline technology.

A higher economic value assigned to the incidence of premature mortality from air pollution.

- Assam: Among the RE technologies assessed in the case of Assam, we find the ERR associated with SHP deployment to be around 11.5 percent. Solar PV sees relatively low returns in Assam: 5.7 and 2.3 percent for ground mounted and rooftop, respectively. The higher rate of return for SHP is primarily driven by the high CUF norm for the technology in the state, which is 50 percent higher than that in the other two states assessed.

Among the three states assessed, Assam sees the lowest rate of return from RE technology deployment, primarily owing to the low health and water impacts for the baseline technology (see Table 7). This is because it has the lowest level of population exposure to air pollution and the lowest economic value of water among the states assessed. This is also why the climate impacts of the baseline technology assume greater relative significance in the case of Assam and have a larger influence on the ERR value than in the other states.

Another consequence of the relatively small magnitude of the impacts in the case of Assam is that grid integration costs constitute a larger share of the total impact and therefore have a greater influence on the ERR value than in the other states. In an alternative scenario (see Table 11) that excludes grid integration costs, the rate of return of RE deployment rises considerably.

We also explored the return from RE deployment relative to a gas baseline, as an alternative scenario, given the historical prevalence of the technology in the state. Here, we found that the rate of return of RE deployment is negative for all RE technologies, because the already low net positive impacts of $\mathrm{RE}$ relative to a coal baseline (in comparison to the other states) drop even further for gas in the health and water impact categories. However, when grid integration costs are excluded, RE technology deployment sees positive returns relative to a gas baseline, as shown in Table 11. Given the relative importance of climate impacts in the state, Table 11 also includes the impact of assuming a lower $\mathrm{CO}_{2}$ intensity of the baseline technology on the Base Case results.

Table 10 | Jharkhand: Results and Scenarios with Alternative Key Inputs

\begin{tabular}{|c|c|c|c|c|c|c|}
\hline & & \multicolumn{3}{|c|}{ ALTERNATIVE RE TECHNOLOGY ASSUMPTIONS } & $\begin{array}{l}\text { ALTERNATIVE } \\
\text { BASELINE } \\
\text { TECHNOLOGY } \\
\text { ASSUMPTIONS }\end{array}$ & $\begin{array}{l}\text { ALTERNATIVE } \\
\text { ECONOMIC } \\
\text { VALUES }\end{array}$ \\
\hline RE TECHNOLOGY & BASE CASE & $\begin{array}{l}\text { LOWER CAPITAL } \\
\text { COST OF SOLAR } \\
\text { PV }(-10 \%)\end{array}$ & $\begin{array}{l}\text { HIGHER CUF } \\
\text { OF SOLAR PV } \\
(+10 \%)\end{array}$ & $\begin{array}{l}\text { USE OF FOREST } \\
\text { LAND FOR } \\
\text { DEPLOYMENT }\end{array}$ & $\begin{array}{l}\text { LOWER COAL } \\
\text { CONSUMPTION } \\
(-10 \%)\end{array}$ & $\begin{array}{l}\text { HIGHER VALUE } \\
\text { PER PREMATURE } \\
\text { DEATH FROM AIR } \\
\text { POLLUTIONa }\end{array}$ \\
\hline $\begin{array}{l}\text { Solar PV ground } \\
\text { mounted }(\%)\end{array}$ & 25.16 & 30.72 & 30.24 & 22.07 & 22.59 & 33.90 \\
\hline $\begin{array}{l}\text { Solar PV rooftop } \\
(\%)\end{array}$ & 23.36 & 29.08 & 28.46 & 23.36 & 20.70 & 32.37 \\
\hline SHP (\%) & 23.17 & NA & NA & 21.39 & 20.47 & 32.30 \\
\hline
\end{tabular}

Notes: CUF = capacity utilization factor; NA = not available; PV = photovoltaic; RE = renewable energy; SHP = small hydro power.

a. Using an upper-bound estimate of the value of statistical life (VSL) of US\$6,38,429 from Majumder and Madheswaran (2018) as compared to $\$ 3,05.546$ based on 0ECD (2012) used in the Base Case.

Source: WRI authors. 


\begin{tabular}{|c|c|c|c|c|c|}
\hline & & \multicolumn{2}{|c|}{ ALTERNATIVE RE TECHNOLOGY ASSUMPTIONS } & \multicolumn{2}{|c|}{$\begin{array}{c}\text { ALTERNATIVE BASELINE TECHNOLOGY } \\
\text { ASSUMPTIONS }\end{array}$} \\
\hline RE TECHNOLOGY & BASE CASE & $\begin{array}{l}\text { LOWER CAPITAL COST } \\
\text { OF SOLAR PV }(-10 \%)\end{array}$ & $\begin{array}{l}\text { GRID INTEGRATION } \\
\text { COSTS EXCLUDED }\end{array}$ & $\begin{array}{l}\text { GAS BASELINE (GRID } \\
\text { INTEGRATION COSTS } \\
\text { EXCLUDED) }\end{array}$ & $\begin{array}{l}\text { LOWER INTENSITY OF } \\
\mathrm{CO}_{2} \text { EMISSIONS }(-10 \%)\end{array}$ \\
\hline $\begin{array}{l}\text { Solar PV ground } \\
\text { mounted (\%) }\end{array}$ & 5.67 & 8.00 & 15.62 & 6.04 & 3.17 \\
\hline $\begin{array}{l}\text { Solar PV rooftop } \\
(\%)\end{array}$ & 2.33 & 4.71 & 13.02 & 2.58 & -1.02 \\
\hline SHP (\%) & 11.45 & NA & 30.65 & 13.44 & 7.61 \\
\hline
\end{tabular}

Notes: CUF = capacity utilization factor; NA = not available; PV = photovoltaic; RE = renewable energy; $\mathrm{SHP}=$ small hydro power

Source: WRI authors

\subsection{Comparison with National Estimates}

Hingne et al. (2020) used the SD Framework to calculate the average returns of RE deployment at the national level, which we recalculated by updating the input data and making minor adjustments to the methodological assumptions for consistency with the state-level calculations. As shown in Table 8, the average values at the national level indicate the highest returns for rooftop solar PV at 24.4 percent, followed by ground-mounted solar PV (24.2 percent), wind (23.8 percent), and SHP (14.1 percent).

It can be seen that the results obtained for each of the three states assessed vary not only in comparison to other states but also with respect to the average results obtained at the national level; this is notable in the case of Maharashtra and Assam, where wind and SHP show better returns than solar PV. This is because the local conditions in each region, as discussed in Section 3.1, significantly affect the interaction between RE technologies and the different impact categories. This again highlights the importance of using the SD Framework with local, context-specific assumptions and data.

Another noteworthy observation from the national results is the higher rate of return associated with rooftop solar PV compared to ground-mounted solar PV at the national level, which is not seen in the Base Case results for any of the three states assessed. In general, the relative attractiveness of the two options is governed by a trade-off between the land-use impact of groundmounted PV against higher costs in the case rooftop PV (due to smaller project scales and the difficulty of access for maintenance). This implies that if the economic value of the land diverted for ground-mounted solar increases sufficiently depending upon the region assessed, the type of land diverted, or increased scarcity over time, its attractiveness relative to rooftop PV is likely to change.

\subsection{Policy Insights and Scope for Future Work}

By quantifying and combining market and non-market costs and the benefits associated with RE technology deployment (relative to the chosen baseline technology) into a single metric, the ERR serves as a convenient summary statistic to support decision-making, when considered along with other relevant parameters, such as the non-monetizable impacts discussed in Section 2.7.1. It can enable policymakers to make more informed decisions to prudently scale the deployment of RE, by providing a quantitative and comparable understanding of the implications of different RE technology options for the use of scarce natural resources, such as land and water, and the impact on local populations within a given region or context. Furthermore, by mapping the assessed impact categories and indicators against the relevant SDGs, the SD Framework can help policymakers better understand the interlinkages between RE and sustainable development, and plan and track progress toward these goals in a more evidence-based manner.

State-specific ERR estimates, such as the ones presented in this analysis for Maharashtra, Jharkhand, and Assam, can enable policymakers in these states to prioritize the right RE technologies and plan improved deployment. This can be done by incorporating the ERR as one of the metrics for the selection of bids for public project allocation and by stipulating requirements for the inclusion of measures to mitigate the identified social and environmental costs in project proposals. For example, the fact 
that avoided water-use impact is the main driver of the returns from RE technology deployment in Maharashtra indicates that relatively less water-intensive RE technologies should be preferentially selected and that supporting policies, such as those addressing water use in electricity generation, should be emphasized. Similarly, the key role of avoided health impacts from air pollution in Jharkhand points to the unsuitability of RE technologies such as biomass, which result in air pollutant emissions. In Assam, the fact that grid integration costs can negate the benefits from RE technologies, such as solar $\mathrm{PV}$, indicates that decentralized RE solutions may be the way forward in the state. Moreover, for states with a high RE potential but low levels of current deployment, such as Jharkhand and Assam, ERR estimates can make a clear case for financial or policy support for $\mathrm{RE}$ technologies that are beneficial to society, which can help these states meet their RE targets by increasing the uptake of such technologies (see Box 4).

\section{Although ERR estimates can provide insight into the key drivers of socioeconomic and environ- mental costs or benefits linked to RE deploy- ment, their use in decision-making warrants a cautious approach that considers the potential} trade-offs across different impact categories, including those not included in our quantitative estimates and across different population subgroups affected by the impacts. For example, RE technologies that are more land intensive in general, compared to a coal baseline, can have implications for agricultural employment, depending upon the type of land diverted for deployment. Land diversion patterns for ground-mounted solar PV in the three states show significant agricultural land use (see Table C2 in Appendix C), which can affect landless farm workers, who lack the skills needed for the alternative job opportunities created by RE. Another example is that of coal-based employment in a state like Jharkhand, which has the highest coal reserves in the country and local economic activity inextricably linked to coal use. Most coal-based jobs in the state, however, are in the informal sector, with workers lacking the agency and skills to take advantage of the alternative job opportunities created by RE (Bhushan et al. 2020), again illustrating a potential trade-off versus RE deployment. In such cases, it is essential to evaluate these trade-offs through consultative processes involving representation from local populations and affected groups, and address these in decision-making.

\section{Box 4 | Interpreting Our Results}

Comparing our Base Case results against an SDR of 8 percent for India (Murty et al. 2020), we see that all the assessed RE technologies, except solar PV in the case of Assam, provide a sufficiently high ERR relative to a coal baseline for the current technology and performance norms. Thus, public investment in these technologies, if required, can be justified. In the case of solar PV in Assam, excluding grid integration costs increases the rate of return sufficiently to meet the project acceptability criterion, indicating the potential viability of decentralized solutions.

Notes: $\mathrm{ERR}=$ economic rate of return; $\mathrm{PV}=$ photovoltaic; $\mathrm{RE}$ = renewable energy; SDR $=$ social discount rate.

Sources: WRI authors.

The availability of more disaggregated datasets and the development of reliable quantification methodologies or valuation metrics in the future, especially for social impacts such as those on jobs and livelihoods, can help improve the robustness of the ERR as a metric to assess the socioeconomic impacts of RE deployment by enabling the inclusion of a larger range of impacts in the quantitative estimates, or by capturing the distributional implications of impacts across different population subgroups, such as those by income or gender, within states. 
Health impacts are calculated as the change in mortality and morbidity attributed to a certain intervention. Fossil fuel power generation involves the combustion of fossil fuels, such as coal, natural gas, or diesel, that result in emissions of particulate matter (PM), oxides of sulfur $\left(\mathrm{SO}_{\mathrm{x}}\right)$ and nitrogen $\left(\mathrm{NO}_{\mathrm{x}}\right)$, and mercury $(\mathrm{Hg})$. Emission of these substances leads to poor local air quality, which harms human health (Garg et al. 2019).

We calculate the health impact for our assessment in two steps. First, we estimate the premature mortality and morbidity impacts from exposure to pollutants ( $\mathrm{PM}, \mathrm{SO}_{\mathrm{x}^{\prime}}$ and $\mathrm{NO}_{\mathrm{x}}$ ) emitted due to the combustion of fossil fuels in the baseline technology scenario. This represents the avoided health impact in the renewable technology scenario since these emissions are zero for the renewable technologies considered in this study. The methods used for these calculations and the associated assumptions are described in Section A.1, Part 1. We then assign an economic value to the health damage (avoided) as explained in Section A.2, Part 2.

In assessing the state-level health impacts, the following key assumptions apply:

- Health impacts are determined in terms of an increase in mortality and morbidity risk, in other words, an increase in the incidence of premature deaths and the number of work-loss days (WLDs) and respiratory hospital admissions (RHAs), respectively, due to pollutant-related illnesses in the population exposed to $\mathrm{PM}_{25^{\prime}} \mathrm{SO}_{x^{\prime}}$ and $\mathrm{NO}_{\mathrm{x}}$ emissions from fossil-fuel- and biomass-based power generation.

- The health risk analysis includes premature mortalities associated with four adult diseases, that is, lung cancer, chronic obstructive pulmonary disease, ischemic heart disease (from reduced blood supply), and stroke, for those older than 25 years, and acute lower respiratory infections (ALRIS) for those younger than 5 years. These diseases are predominant among populations exposed to pollutants and increase the mortality risk.

- Health impacts are estimated purely on the basis of exposure to pollutants emitted during power generation over the lifetime of the installed power per unit (MW) of installed capacity.

- For each state, the impacts were estimated for a representative plant of supercritical coal technology within a radius of $50 \mathrm{~km}$.

- The health impact estimates assume the emissions from natural-gasbased power generation to be zero. This is mainly due to the negligible $\mathrm{PM}_{25}$ (less than 1 micrometer in size), $\mathrm{SO}_{\mathrm{x}^{\prime}}$ and $\mathrm{NO}$ emission associated with the combustion of natural gas (EPA $\left.n_{1} d_{1,} 2018\right)$.

\section{A.1 Part 1: Estimating Premature Mortality and Mor- bidity Impacts}

\section{A.1.1 Step 1: Calculating Ambient Pollutant Concentration from the Selected Coal Power Plant}

The first step is to calculate the ambient concentration of pollutants emitted from the power plant. This is done in two sub-steps, using modules adopted from Walvekar et al. (2019):

- Coal power stack emission (CPSE) module: To estimate the emission rate of pollutants, given the specifications of the fuel and power plant (see Section A.1.1.1 for details)

- Dispersion module: To estimate the atmospheric concentration of pollutants, given their emission rate from the preceding sub-step, plant-specific technical parameters, and local meteorological data (see Section A.1.1.2 for details)
Both modules require a variety of plant-specific data. However, although coal-based power generation makes up 62 percent of the electricity supply in India, standardized monitoring and reporting of power plants' technical characteristics is lacking. Hence, to adapt the module to statelevel assessment, input data were sourced via the following approaches, in order of priority:

- Publicly available plant-specific data published by the state or national government authorities.

- When plant-specific data were not available, input data and national averages published by either national regulatory authorities or peerreviewed papers were used for a power plant type that best represents the power plant selected.

- WRI air quality experts.

A.1.1.1 Air Pollutant Emissions from the Power Plant Using the CPSE Module

The central public sector enterprise (CPSE) module calculates the $\mathrm{PM}_{2.5^{\prime}}$ $\mathrm{SO}_{\mathrm{x}}$, and $\mathrm{NO}_{\mathrm{x}}$ emission rates from the power plant. The CPSE module is a multi-year emission analysis module that uses plant-specific technological specifications and fuel consumption to calculate the power plant's stack emission rate in $\mathrm{g} / \mathrm{s}$, for each of the three pollutants, using the following equations (the input parameters for the equations used in the case of each state are specified in Table A1):

$$
\begin{aligned}
& \text { Eq. 1: } E R_{P M_{2.5}}(g / s)=(C C x A)_{z} x\left(1-A_{r}\right) \times(1-\eta) \times D \times K \\
& \text { Eq. 2: } E R_{N O_{x}}(g / s)=C C \times E F_{N O_{x}} x D \\
& \text { Eq. 3: } E R_{S O_{x}}(g / s)=C C \times S \times \frac{M W_{p}}{M W_{f}} \times(1-S r) \times(1-\dot{\eta}) \times D
\end{aligned}
$$

where:

$C C$ : Total coal consumer (kt),

$A$ : Ash content in coal (\%),

$A_{r^{\prime}}$ Fraction of ash retained,

z: Particulate size,

$\eta$ : Control efficiency (\%),

D: Plant technology factor,

$K$ : Factor of particulate fraction by size,

$E F$ : Emission factor (t/kt),

$S$ : Fraction of sulfur content in coal,

$M W_{p}$ : Molecular weight of pollutant $(\mathrm{g} / \mathrm{mol})$,

$M W_{f^{\prime}}$ Molecular weight of fuel $(\mathrm{g} / \mathrm{mol})$,

$S_{r}:$ Sulfur retained, and

$\eta$ ': Control efficiency of desulfurization technology. 
Table A1 | Input Parameters of the CPSE Module

\begin{tabular}{|c|c|c|c|c|}
\hline \multicolumn{5}{|c|}{ INPUT PARAMETERS OF THE CPSE MODULE } \\
\hline INPUT PARAMETERS & UNIT & ASSAM & JHARKHAND & MAHARASHTRA \\
\hline Name of Plant & & Bongaigaon STPP & Tenughat STPP & Mauda STPP \\
\hline Plant Capacity & MW & 750 & 1,320 & 1,320 \\
\hline Total Coal Consumption (CC) & MT/year & $31,53,333$ & $48,00,000$ & $52,33,333$ \\
\hline \multicolumn{5}{|c|}{ PM 2.5} \\
\hline Ash Content in Coal $(A)$ & $\%$ & $34 \%$ & $39 \%$ & $34 \%$ \\
\hline Fraction of Ash Retained $\left(A_{r}\right)$ & & 2 & 2 & 1.5 \\
\hline Control Efficiency $(\eta)$ & $\%$ & 99.61 & 99.61 & 99.61 \\
\hline Plant Technology Factor $(D)$ & & 1 & 1 & 1 \\
\hline $\begin{array}{l}\text { Factor of Particulate Fraction by } \\
\text { Size }(K)\end{array}$ & & 0.75 & 0.75 & 0.75 \\
\hline \multicolumn{5}{|c|}{$\mathrm{NO}_{\mathrm{x}}$} \\
\hline Emission Factor of $\mathrm{NO}_{\mathrm{x}}\left(E F_{x}\right)$ & $\mathrm{kg} / \mathrm{MT}$ & 2.64 & 2.64 & 2.64 \\
\hline Plant Technology Factor $(D)$ & & 1 & 1 & 1 \\
\hline \multicolumn{5}{|c|}{$\mathrm{SO}_{\mathrm{x}}$} \\
\hline $\begin{array}{l}\text { Fraction of Sulfur Content in } \\
\text { Coal }(S)\end{array}$ & $\%$ & $0.60 \%$ & $0.60 \%$ & $0.60 \%$ \\
\hline $\begin{array}{l}\text { Molecular Weight of Pollutant } \\
\left(M W_{p}\right)\end{array}$ & $(\mathrm{g} / \mathrm{mol})$ & 64 & 64 & 64 \\
\hline $\begin{array}{l}\text { Molecular Weight of Fuel } \\
\left(M W_{f}\right)\end{array}$ & $(\mathrm{g} / \mathrm{mol})$ & 86 & 86 & 86 \\
\hline Sulfur Retained ( $\mathrm{Sr}$ ) & $\%$ & $30 \%$ & $30 \%$ & $30 \%$ \\
\hline Control Efficiency $\left(\eta^{\prime}\right)$ & & 0 & 0 & 0 \\
\hline Plant Technology Factor $(D)$ & & 1 & 1 & 1 \\
\hline
\end{tabular}

Notes: $\mathrm{CPSE}=$ central public sector enterprise; $\mathrm{g} / \mathrm{mol}$ = grams per mole; $\mathrm{kg}$ = kilogram; $\mathrm{MT}=$ metric ton; $\mathrm{MW}$ = megawatt; $\mathrm{STPP}=$ supercritical thermal power project.

Sources: CERC 2018b; Guttikunda and Jawahar 2014; MoEFCC 2010; Walvekar et al. 2019.

\section{A.1.1.2 Dispersion of Emissions around the Power Plant}

\section{A.1.1.2.1 Estimate Ambient Concentration of Primary PM}

The dispersion module uses a steady-state Gaussian Plume model to estimate the concentration of the pollutant emissions in the ambient air around the power plant based on the stack emission rates calculated in the previous step, stack specifications, and meteorological data. The used input parameters and their values are summarized in Table A2. The output of the module is the monthly ambient air pollutant concentrations $\left(\mu \mathrm{g} / \mathrm{m}^{3}\right)$ at ground level at varying kilometer intervals i, from the power plant. We take the annual average value of these monthly values of PM 2.5 concentrations for the purpose of our calculations described in Section A.1.1.2.3. 
Table A2 | Summary of the Inputs of the Gaussian Plume Dispersion Model

INPUTS OF THE GAUSSIAN PLUME DISPERSION MODEL

TECHNICAL CHARACTERISTICS OF THE BASELINE THERMAL POWER PLANTS CHOSEN

\begin{tabular}{|c|c|c|c|c|}
\hline & & Assam & Jharkhand & Maharashtra \\
\hline & & Bongaigaon STPP & Tenughat STPP & Mauda STPP \\
\hline Power Plant Capacity & MW & 750 & 1,320 & 1,320 \\
\hline Stack Height & $\mathrm{m}$ & 275 & 275 & 275 \\
\hline Stack Top Inlet Diameter & $\mathrm{m}$ & 7 & 7 & 7 \\
\hline Stack Gas Exit Velocity & $\mathrm{m} / \mathrm{s}$ & 26.43 & 26.43 & 26.43 \\
\hline Stack Gas Temperature & K & 439 & 439 & 439 \\
\hline Receptor Height above Ground & $\mathrm{m}$ & 0 & 0 & 0 \\
\hline Urban (U) or Rural (R) & & $\mathrm{R}$ & $\mathrm{R}$ & $\mathrm{R}$ \\
\hline \multicolumn{5}{|c|}{ GEOGRAPHICAL COORDINATES } \\
\hline Latitude & & 26.5129 & 23.7573 & 21.1797 \\
\hline Longitude & & 90.5494 & 85.8936 & 79.3972 \\
\hline \multicolumn{5}{|c|}{ CPSE MODULE OUTPUT } \\
\hline $\mathrm{PM}_{2.5}$ Emission Rate & $\mathrm{g} / \mathrm{s}$ & 97.95 & 173.09 & 162.56 \\
\hline $\mathrm{NO}_{\mathrm{x}}$ Emission Rate & $g / s$ & 263.98 & 401.83 & 438.10 \\
\hline $\mathrm{SO}_{\mathrm{x}}$ Emission Rate & $\mathrm{g} / \mathrm{s}$ & 312.53 & 475.74 & 518.68 \\
\hline
\end{tabular}

Notes: $\mathrm{CPSE}=$ central public sector enterprise; $\mathrm{g} / \mathrm{s}=$ grams per second; $\mathrm{K}=$ kelvin; $\mathrm{kg}=$ kilogram; $\mathrm{m} / \mathrm{s}=$ meters per second; $\mathrm{MW}=$ megawatt; $\mathrm{NO} 0_{\mathrm{x}}=$ nitrogen oxides; $\mathrm{SO}{ }_{\mathrm{x}}=\mathrm{sulfur}$ oxides; $\mathrm{STPP}$ = supercritical thermal power project.

Sources: CERC 2018b; MoEFCC 2010; Walvekar et al. 2019.

\section{A.1.1.2.2 Account for Secondary PM 25 Formation from SO and NO} Since $\mathrm{SO}_{\mathrm{x}}$ and $\mathrm{NO}$ emissions do not have a direct dose-dependent health risk except at high concentrations (Chen et al. 2007), we estimate their health impacts by accounting for the health risk caused by secondary $\mathrm{PM}_{2.5}$ formed by these pollutants in the atmosphere. To do so, we use the approach proposed by NACAAP (2011). First, we use the following equation to estimate the emission rate of secondary $\mathrm{PM}_{25^{\prime}}$

$$
\text { Secondary } P M_{2.5} E R(g / s)=P M_{2.5} E R+\frac{S O_{x} E R}{4 O}+\frac{N O_{x} E R}{2 O O}
$$

where

ER: Emission Rate, $P M_{2.5} E R, S O_{x} E R$, and $N O_{x} E R$ are the outputs from the CPSE module in grams per second $(\mathrm{g} / \mathrm{s})$.

\section{A.11,2,3 Calculate the Total PM $_{25}$ Concentration}

We then use the following equation (NACAAP 2011) to arrive at the Total $P M_{25 i}$ in $\left(\mu \mathrm{g} / \mathrm{m}^{3}\right)$ for different distances $i$, up to a limit of $50 \mathrm{~km}$, using the results from the previous two steps. This final concentration value is used in our mortality and morbidity calculations in Section A.1.3.
Total $P M_{2.5 i}\left(\mu \mathrm{g} / \mathrm{m}^{3}\right)=$ Primary $P M_{2.5 i}\left(\mu \mathrm{g} / \mathrm{m}^{3}\right) x \frac{\text { Secondary } P M_{2.5} E R}{P M_{2.5} E R}$

where

Primary $P M_{2.5 i}$ in $\mu \mathrm{g} / \mathrm{m}^{3}$ is the $\mathrm{PM}_{2.5}$ emissions output from the Gaussian Plume model at distance $i$ from the point source as calculated in Section A.1.1.2.1,

Secondary $P M_{25}$ ER in $\mathrm{g} / \mathrm{s}$ is the estimated emission rate of secondary $\mathrm{PM}_{2.5}$ as calculated in Section A.1.1.2.2, and

$P M_{2.5} E R$ in $\mathrm{g} / \mathrm{s}$ is the emission rate calculated by the CPSE module.

A.1.2 Step 2: Calculating the Size of the Population Exposed to the Pollution

The next step is to calculate the size of the population exposed to the ambient pollution concentrations at different distances from the power plant calculated in Section A.1.1. The incremental change in population at different distances from the power plant is calculated for each state using the local gridded population count and geographic information systems (GIS) modeling. 
The GIS software allows us to combine non-spatial and spatial data, and analyzes the spatial information output. We use the gridded population data (segregated by age) published by the Gridded Population of World Version 4.11 (GPWv4.11) (SEDAC n.d.), which uses the Indian Census 2011 as its source, as input to the GIS software. The GPWv4.11 estimates the number of persons per 30 arc seconds (approximately $1 \mathrm{~km}$ ). This gridded population and with the spatial map of the selected power plant are entered into the GIS modeling software to arrive at the number of persons residing in each circular area of radius $n$ and $n+1$ kilometers. For example the population concentration change $30 \mathrm{~km}$ away from the power plant is the number of residents within a circular area of radius $30 \mathrm{~km}$ minus the number of residents within $29 \mathrm{~km}$. Thus, we arrive at the value for the exposed population at each distance $i$, denoted as $P_{i^{i}}$. We conservatively assume no increase in population over the assessment period.

\section{A.1.3 Step 3: Calculating Mortality and Morbidity Associated with Exposure}

\section{A.1.3.1 Increase in Mortality (Premature Deaths)}

For this report, we use the health risk module by Walvekar et al. (2019) to estimate the increase in mortality or premature deaths among the exposed population (within a $50 \mathrm{~km}$ radius) associated with emissions from the power plant. The module quantifies the mortality impact of premature mortalities associated with four adult (for those older than 25 years) diseases, that is, lung cancer, chronic obstructive pulmonary disease, ischemic heart disease (from reduced blood supply), and stroke, as well as ALRIs (for those younger than 5 years). This is based on the level of exposure of the exposed population and the corresponding relative risk of premature mortality due to the illness. The relative risk depends on the age, gender, and concentration of the pollutant and is sourced from Apte et. al (2015). The increase in premature mortality from these diseases due to exposure is calculated using the following equation:

$$
\Delta D=\sum_{i} \sum_{s}\left(e^{\alpha_{s}+\Delta C i}-1\right) * P_{i}^{*} I
$$

where

$\Delta D$ is the increase in annual premature deaths.

$\alpha_{\mathrm{s}}$ is the coefficient from the concentration-response function. The coefficient indicates the increase in mortality by illness $s$ per unit increase in PM 2.5 concentration.

$\Delta C_{i}$ is the increase in ambient air concentration of $\mathrm{PM}_{25}$ (annual average) at distance i from the power plant, as calculated in Section A.1.1.

$P_{i}$ is the exposed population at a distance i from the power plant, as calculated in Section A.1.2.

$I$ is the baseline incidence rate for annual premature mortality among the exposed population.

We divide the annual increase in mortality thus calculated by the total installed capacity of the power plant to obtain the annual premature mortality per unit of installed capacity. These values for the three states (mean, lower bound, and upper bound) are shown in Table A3. We consider the mean value for our calculations.
Table A3 | Mortality Estimates for the Three States

INCREASE IN PREMATURE MORTALITY (DEATHS/MW/YEAR)

$\begin{array}{lccc}\text { STATE } & \text { MINIMUM } & \text { MEAN } & \text { MAXIMUM } \\ \text { Maharashtra } & 0.0178 & 0.1745 & 0.6260 \\ \text { Jharkhand } & 0.0498 & 0.3248 & 0.8903 \\ \text { Assam } & 0.0126 & 0.1465 & 0.6355\end{array}$

Note: MW = megawatt.

Sources: WRI authors, based on Walvekar et al. (2019) and Apte et al. (2015)

\section{A.1.3.2 Increase in Morbidity}

We estimate the increase in morbidity among the exposed population (within a $50 \mathrm{~km}$ radius) associated with emissions from the power plant using two of the most common representations of morbidity incidence, that is, respiratory hospital admissions (RHAs) and work-loss days (WLDs) due to illness, following the approach proposed in Gunatilake et al. (2014) and applied by Srinivasan et al. (2018). These are calculated using the following equation:

$$
\Delta I_{m}=\Delta C_{i} \times P_{i} \times D R F_{m}
$$

where

$\Delta I_{m}$ is the increase in the number of annual morbidity instances of type $m$, that is, RHA or WLD.

$\Delta C_{i}$ is the increase in the ambient air concentration of $\mathrm{PM}_{2.5}$ (annual average) at distance i from the power plant $\left(\mu \mathrm{g} / \mathrm{m}^{3}\right)$, as calculated in Section A.1.1.

$P_{i}$ is the exposed population at a distance $i$ from the power plant, as calculated in Section A.1.2.

$D R F_{R H A}$ is 0.13 instances per person per $1 \mu \mathrm{g} / \mathrm{m}^{3}$ increase in $\mathrm{PM}_{2.5}$ concentration.

$D R F_{W L D}$ is 0.0315 days per person per $1 \mu \mathrm{g} / \mathrm{m}^{3}$ increase in $\mathrm{PM}_{2.5}$ concentration.

We divide the annual increase in RHAs and WLDs thus calculated by the total installed capacity of the power plant to obtain an estimate of the instances of morbidity per unit of installed capacity. These values for the three states are shown in Table A4.

Table A4 | Morbidity Estimates for the Three States

\section{INCREASE IN MORBIDITY (INSTANCES/MW/YEAR)}

\begin{tabular}{lcc|}
\hline STATE & WLD & RHA \\
\hline Maharashtra & 14.83 & 612.18 \\
\hline Jharkhand & 27.38 & $1,130.14$ \\
\hline Assam & 11.58 & 477.88 \\
\hline
\end{tabular}

Notes: $\mathrm{MW}=$ megawatt; $\mathrm{RHA}=$ respiratory hospital admissions; $\mathrm{WLD}=$ work-loss day. Sources: WRI authors, based on Gunatilake et al. (2014) and Srinivasan et al. (2018) 


\section{A.2 Part 2: Economic Valuation of Mortality and Mor- bidity Impacts}

\section{A.2.1 Step 1: Economic Value of Mortality}

To monetize mortality outcomes, we estimate the value of statistical life (VSL), defined as the monetary value society is realistically willing to pay to save one statistical life, for India using the human capital approach in OECD (2012). This value is used in our Base Case results. Due to the wide range of VSL estimates across studies, we use two alternative values (Cropper et al. 2019; Majumder and Madheswaran 2018) as additional scenarios, thus incorporating the variation in VSL estimates for India. All monetary estimates are converted to INR (2017 price levels). These are summarized in Table A5.

Table A5 | VSL Estimates for India

\section{VSL FOR INDIA (2017 \$)}

$\begin{array}{lc}\text { Mortality Risk Value (\$) Mid-Range (Base Case) } & 3,05,546 \\ \text { Mortality Risk Value (\$) Upper Bound } & 6,38,429 \\ \text { Mortality Risk Value (\$) Lower Bound } & 90,384\end{array}$

Notes: VSL = value of statistical life.

Sources: OECD 2012; Majumder and Madheswaran 2018; Cropper et al. 2019.
The annual economic value of the avoided mortality from the deployment of $1 \mathrm{MW}$ of RE technology (assuming zero air pollution for the RE technology, as is the case for the RE technologies assessed in this study) can now be estimated as

$$
H I_{b, t}=\Delta D_{b} x \operatorname{VSL} \times \frac{C U F_{t}}{C U F_{b}}
$$

where

$H I_{b, t}$ is the annual economic value of the avoided mortality in $\$$.

$\Delta D_{b}$ is the increase in the number of premature deaths annually per megawatt deployment of baseline technology $b$ calculated in Section A.1.3.1.

$V S L$ is the value of statistical life in $\$$.

$C U F_{t}$ is the capacity utilization factor of renewable technology t.

$C U F_{b}$ is the capacity utilization factor of the baseline technology $b$.

\section{A.2.2 Step 2: Economic Value of Morbidity}

To monetize morbidity outcomes, we first assign monetary values to a WLD and a case of RHA. For the former, we conservatively use the average daily wage rate of INR 320 for unskilled workers (MoEL 2017). For the latter, we compare the estimate of the average cost of hospitalization in the state (MoHFW 2014) with the cost of an RHA case estimated by Gunatilake et al. (2014), and conservatively choose the lower of the two values.

We then calculate the economic value of the annually avoided WLDs and RHAs from the deployment of RE technology relative to the baseline, in a similar manner as done for mortality in Step 1. The two are then summed to arrive at the economic value of the annually avoided morbidity. All monetary estimates are converted to 2017 price levels. 
India's thermal power generation relies heavily on freshwater withdrawals for its cooling technology. With recent droughts and water storages, the country is losing substantial power generation (Luo et al. 2018). Even with strict water regulations limiting water withdrawals to $3.5 \mathrm{~m}^{3} / \mathrm{MWh}$ for old power plants, and $2.5 \mathrm{~m}^{3} / \mathrm{MWh}$ for post-2017 new power plants (MoEFCC 2015), Luo et al. (2018) found that the country continued to be at risk of power outages. Although 99 percent of the water withdrawn may be returned to rivers and lakes and become available for use, water consumption within the power plants remains significant (Chaturvedi et al. 2017; Luo et al. 2018). Luo et al. (2018) estimated water consumption by a thermal power plant as 2.1 billion cubic meters in 2016.

On the other hand, RE technologies, such as solar PV and wind, require zero to minimal water for power generation. Water consumption in solar $\mathrm{PV}$ generation is mainly for cleaning panels, and wind power generation withdraws no water. Thus, to evaluate the water-use impact of an RE technology, we calculated the avoided generation-related water use, which is the additional water that would have been used by our baseline case power plant for power generation.

\section{B.1 Step 1: Measure Avoided Water Use}

The first step in calculating the water impact associated with RE technology power generation is to estimate the avoided water use, which is the additional water that would have been used for fossil fuel power generation. To evaluate this, we calculate the net avoided water intensity, which is the difference between the water-use intensities for fossil-fuel-based power generation and RE technology power generation.

The water-use requirements of power plants depend mainly on the cooling technology employed. In 2019, the Central Electricity Authority (CEA) mandated that power plants should monitor and report their actual annual water consumption, the type of water source, and the water management measures undertaken (CEA n.d.; Kumar and Jairaj 2019). These norms would help enforce greater transparency and resource management. However, these values have not been publicly disclosed yet, and so we use the India-specific water consumption estimates provided by Chaturvedi et al. (2017) for fossil-fuel-based power plants and Luo et al. (2018b) and IRENA and WRI (2018) for the different RE technologies. These values are listed in Table B1.

\section{Table B1 | Water Intensity of Power Generation}

WATER INTENSITY OF POWER GENERATION ( $\left.\mathrm{M}^{3} / \mathrm{MWH}\right)$

\begin{tabular}{lr}
\hline TECHNOLOGY & WATER INTENSITY \\
\hline Baseline-Coal & 2.590 \\
\hline Baseline-Gas & 1.620 \\
\hline Solar PV & 0.080 \\
\hline Solar Rooftop & 0.080 \\
SHP & 0.000 \\
\hline Wind & 0.000 \\
\hline
\end{tabular}

Notes: $\mathrm{m}^{3} / \mathrm{MWh}=$ cubic meters per megawatt-hour; SHP = small hydro power.

Sources: Chaturvedi et al. 2017; IRENA and WRI 2018.

\section{B.2 Step 2: Determine the TEV of Water}

The total economic value (TEV) of water is estimated by using a two-step valuation that accounts for changes in the current and future water stress and the basin population specific to the region. We use two tools that help us arrive at the TEV of water: (i) WRI's Aqueduct 3.0 Water Risk Atlas and (ii) GIZ's Global Water Valuation. The two tools collectively give us the shadow price of water in $\$$ per cubic meter of water, which we refer to as the TEV of water in our report.

\section{B.2.1 Estimating the Water Risk Score Using Aqueduct 3.0 Water Risk Atlas}

WRI's Aqueduct 3.0 Water Risk framework combines multiple waterrelated risks to estimate the local-level water scarcity levels for each latitude and longitude during 2014, 2030, and 2040. The tool integrates water withdrawals from multiple sources, such as domestic, industrial, agriculture, and livestock, and the availability of renewable surface and groundwater supplies. It also accounts for the impact on upstream water consumption and downstream renewable water availability for large dams (Hofste et al. 2019).

This open-source tool uses the geographic coordinates of the region as input. It utilizes hydrologic models and ordinary least square regression to compute the baseline annual and future projections of water-related risk datasets (Hofste et al. 2019). This dataset gives us the baseline water stress, baseline water depletion, seasonal variability, inter-annual variability, and groundwater table depletion, and the future projections of water stress, water supply, water demand, and seasonal variability under three scenarios: (i) the SSP2 RCP8.5 pessimistic, (ii) business as usual (BAU), and (iii) SSP2 RCP4.5 optimistic pathways. Details of these scenarios can be found in Hofste et al. (2019). Table B2 summarizes the water stress labels and score estimated by Aqueduct 3.0 for each state, which function as inputs to the GIZ Global Valuation Tool in Section B.2.2. A higher score indicates more significant water stress; that is, zero means the region is least water stressed, and five means the region is most water stressed.

\section{Table B2 | Water Stress Labels and Scores for Each State per Aqueduct 3.0}

\section{WATER STRESS LEVEL}

\begin{tabular}{|lcccc|}
\hline Maharashtra & $\begin{array}{c}\text { Extremely high } \\
(>80 \%)\end{array}$ & 4.70 & 4.18 & 4.15 \\
\hline Jharkhand & $\begin{array}{c}\text { Medium-high } \\
(20-40 \%)\end{array}$ & 1.34 & 2.15 & 2.28 \\
\hline Assam & Low $(<10 \%)$ & 0 & 0 & 0 \\
\hline
\end{tabular}

Source: Aqueduct 3.0 


\section{B.2.2 Estimate the TEV of Water Using the GIZ Global Water Valuation Tool}

The joint GIZ, NCD, and VfU Global Water Valuation tool is an open-source tool that calculates the total economic value of water (TEV) for 2014, 2030, and 2040 based on the water stress exposure of a geographical location based on the Aqueduct dataset (Ridley and Boland 2015). The tool utilizes a hybrid approach that combines the value function for agriculture use, municipal supply, impact on human health, and ecosystem damage due to water scarcity as a function of the baseline water stress. The tool provides the option to apply shadow prices to quantities of water. This cost per cubic meter $\left(\mathrm{m}^{3}\right)$ varies for each location in line with the projected ratios of supply and demand for freshwater resources. The resulting costs are aggregated to create an overall "shadow water cost" as a leading indicator of exposure to future constraints on access to resources. This can be due to a combination of expected changes in demand and supply. It also adjusts for the size of the region's population, where we use approximations to arrive at the basin-level population. The tool uses local parameters to assess the demand and supply, and also values water based on local tariffs. In this publicly available tool, we update the initial value of the disability-adjusted life years for India based on the 2017 values published by the World Bank, which the tool projects for 2030 and 2040. All monetary estimates are converted to INR (2017 price levels).

The economic value of the avoided water-use impact per megawatt-hour of electricity generated for an RE technology ( $\mathrm{t}$ ) is then estimated as

\section{-Net Water}

where

Net Water Intensity of Power Generation is the difference in the intensity of water use $\left(\mathrm{m}^{3} / \mathrm{MWh}\right)$ between RE technology t and coal technology (the baseline).

$\sum_{c}$ Economic Value of Water is the overall shadow water cost or TEV of water, calculated by summing the alternative uses of water (or the opportunity costs) across different water-use categories $\mathrm{c}$ for a given region, as described in Section B.2.2. The values used for each state are shown in Table B3.

Table B3 | TEV of Water or Shadow Price of Water

\begin{tabular}{llcc}
\hline & \multicolumn{4}{l}{ TEV OF WATER 2017 (\$) } \\
\hline Maharashtra & 2014 & 2030 & 2040 \\
\hline Jharkhand & 13.11 & 11.21 & 11.10 \\
\hline Assam & 2.37 & 4.13 & 4.33 \\
\hline India & 1.01 & 1.01 & 1.01 \\
\hline
\end{tabular}

Note: TEV = total economic value

Sources: GIZ Global Water Valuation Tool.

Finally, the total avoided water-use impact is calculated as the product of the annual electricity generated (in megawatt-hours) per megawatt of installed RE capacity and $W I_{t^{\prime}}$ 
Land is a resource that is vital for all on-land energy technology and infrastructure development. However, land-use and land cover changes have multidimensional impacts on social and environmental components and jeopardize financial investments (Rai et al. 2018). A study by Kiesecker et al. (2020) estimates that the total land required to achieve the rest of India's NDC target of $175 \mathrm{GW}$ installed RE by 2030, post 2017, ranges from approximately 55,000 to $125,000 \mathrm{~km}^{2}$. The study further estimates that land diversions for solar alone could range from 6,700 to $11,900 \mathrm{~km}^{2}$ of forest and $24,100-55,700 \mathrm{~km}^{2}$ of agriculture. Agricultural land diversion for RE deployment could indirectly also lead to further deforestation to replace lost cultivated land.

We estimate the direct impact on land use land cover (LULC) changes due to RE technology deployment to calculate the land impact. We first examine the land requirements for each RE technology and then estimate the social and economic cost of forest land and the opportunity cost of agriculture land diversion.

\section{C.1 Step 1: Estimate Land-Use Intensity}

The land-use intensity, Land Intensity ${ }_{t}$ is the land required to install one unit of a given technology and depends on the type of RE technology deployed. Land requirements for a ground-mounted solar PV unit would depend on the PV technology used, terrain, tracking systems used, geographic location, and the design of the field. The land requirement for wind depends on the turbine technology and land topography (Kumar and Thapar 2017)

For our study, we use the land intensity values estimated by Gulati and Kacker (2016) and Kumar and Thapar (2017). Due to the lack of published data on the average land requirement for gas thermal power deployment we use the actual land used to set up the Lakwa Gas Thermal Power plant to arrive at the land-use intensity for gas thermal power technology (APGCL 2013).

\section{Table C1 | Land-Use Requirement for Each Power Technology}

\begin{tabular}{lc}
\hline \multicolumn{2}{c}{ LAND-USE REQUIREMENT } \\
\hline TECHNOLOGY & LAND-USE INTENSITY (ha/MW) \\
\hline Baseline-Coal & 0.647 \\
\hline Baseline-Gas & 0.450 \\
Ground Mount Solar PV & 2.000 \\
Rooftop Solar PV & 0 \\
Wind & 1.200 \\
SHP & 1.35 \\
\hline
\end{tabular}

Notes: ha = hectare; MW = megawatt; PV = photovoltaic; $S H P=$ small hydro power. Sources: Gulati and Kacker 2016; Kumar and Thapar 2017.

\section{C.2 Step 2: Identify Relevant Land Impacts}

The geographical location of the land is a vital variable in the installation of an RE technology project, especially for wind and solar PV. These RE technologies depend on geo-specific technical variables, such as wind speed density and solar irradiation.

In its goal to prevent and minimize any agricultural and forest land diversion, the Ministry of New and Renewable Energy (MNRE) promotes and prioritizes the use of barren land and wasteland for RE deployment (Gulati and Kacker 2016). India's wasteland is estimated to have the potential of harnessing $300 \mathrm{GW}$ of wind, $750 \mathrm{GW}$ of solar, and $25 \mathrm{GW}$ of bioenergy (MNRE 2020), which is abundant enough to enable India to not just achieve its 2030 NDC goal but also surpass it. Furthermore, India's central government and state governments promote and incentivize farmers to build solar plants on barren agricultural lands through schemes such as the Kisan Urja Suraksha Evam Utthaan Mahabhiyan (CCEA 2019). Therefore, the underutilization of wasteland for RE deployment cannot be due to lack of availability, potential, or supporting schemes. However, RE technologies' land requirements also depend on the availability of contiguous land (Kumar and Thapar 2017), and in some instances may lead to the intake of cultivable or forest land. The Right to Fair Compensation and Transparency in Land Acquisition, Rehabilitation and Resettlement Act, 2013 (LARR 2013) protects the rights of farmers and landowners, ensuring fair and just compensation to, and provisions for helping, landowners and other affected families. The Act also mandates that agricultural and forest land be procured only as a last resort.

Land-use statistics in India are collected in the form of a ninefold classification. The 329 million hectares are categorized as one of the following: forest land, areas under non-agricultural uses, barren and un-culturable land, permanent pastures and other grazing lands, land under miscellaneous tree crops, culturable wasteland, fallow land other than current fallows, and current fallows (MoSPI n.d.). We have classified land use into three broad categories for the ease of assessment of our analysis: forest land, cultivable land (or agriculture land), and barren land (or wasteland).

We assess possible future or current land-use diversions due to RE deployment depending on data availability for our analysis. We first locate all RE technology project sites in the state. For this, we refer to the Wind Atlas survey, published by the National Institute of Wind Energy (NIWE), to locate future potential wind project sites. The Atlas lists all the potential installable wind sites mapped across the country for wind densities at 50 m, 80 m, and 100 m (MEDA 2016; NIWE n.d.). The dataset accounts for and excludes sites located in topographies not suitable for setting up wind farms and other developments such as road, railways, protected area, and land area at an elevation of more than $1500 \mathrm{~m}$ and with slopes of more than $20^{\circ}$.

Due to the lack of data on potential future solar, small hydro power (SHP), and thermal power plants, we use historical data, assuming that these land-use change trends will continue in the future. To locate the solar and SHP plant sites, we referred to the consolidated installed RE project statewise list published by CEA (CEA 2020a). We consulted the Global Power plant database published by Global Energy Observatory et al. (2018) for all the existing fossil-fuel-based power plants in the states. An important variable for our estimation is the geographical coordinates of each of the power plant sites. For datasets, in our case CEA (2019b), that did not provide these coordinates, we used the open-source OpenCage Geocoding API on Python to extract the approximate location. 
Finally, we used geographic information systems (GIS) to combine the non-spatial geographical coordinates of power plants and spatial LULC maps released by the Indian Space Research Organisation (ISRO) to arrive at an accurate land-use diversion estimate for each power technology under review for each state. Table C2 summarizes these estimates.

\section{Table C2 | Land-Use Patterns Estimated}

\section{LAND-USE PATTERN (\%)}

TECHNOLOGY

MAHARASHTRA

JHARKHAND

ASSAM

I. BASELINE-COAL

Forest land diverted (\%)

11

17

0

Agricultural land diverted (\%)

44

83

100

Wasteland used (\%)

45

India

6.47

0

0

8.68

8.83

II. BASELINE-GAS

Forest land diverted (\%)

Agricultural land diverted (\%)

NA

NA

26

Wasteland used (\%)

NA

NA

74

III. SOLAR PV

Forest land diverted (\%)

46

NA

0

Agricultural land diverted (\%)

50

16

0

Wasteland used (\%)

4

84

100

IV. SOLAR ROOFTOP

Forest land diverted (\%)

0

Agricultural land diverted (\%)

0

Wasteland used (\%)

0

0

0

V. SHP

Forest land diverted (\%)

Agricultural land diverted (\%)

13

0

0

Wasteland used (\%)

82

5

0

0

\section{WIND}

Forest land diverted (\%)

Agricultural land diverted (\%)

Wasteland used (\%)

39

17

44

0

0

Note: $\mathrm{NA}=$ not available; $\mathrm{PV}=$ photovoltaic; $\mathrm{SHP}=$ small hydro power.

Sources: CEA 2020a; Global Energy Observatory et al. 2018; MEDA 2016; NIWE n.d.; WRI authors. 


\section{C.3 Step 3: Estimate Economic Value of Land Diversion}

\section{C.3.1 Opportunity Cost of Agricultural Land Diversion}

The economic value of the agricultural land diverted is estimated as the agricultural income forgone or lost by farmers from being unable to use agricultural land for cultivation. We compute this value by calculating the weighted average of adjusted productivity (INR/ha) of each crop in the state. The four critical variables used for our evaluation are the total production of the crop, the total area occupied by the crop, the price of the harvest, and the share of the total land area used to cultivate the crop The Directorate of Economics and Statistics periodically publishes these values in the Farm Harvest Prices of Principal Crops in India and Land Use Statistics at a Glance, which report the yield and agriculture wholesale price, and the area under each crop, respectively, for each state (EANDS n.d.). All monetary estimates are converted to 2017 price levels.

We use the following formula to calculate the average income per acre for each crop:

$$
P_{c}=\frac{\text { Total production of crop } c}{\text { Total Area occupied by crop c }} \times \text { Price of crop } c
$$

The value of $P_{c}$ is then used to calculate the average agricultural income per acre of the crop for the region. From the land-use statistics released by the Directorate of Economics and Statistics, Ministry of Agriculture, we can compute each crop yield's weight in the market. We can then take the weighted average of the average agricultural income per acre for a farmer (I) by using the following formula:

$$
I=\left(P_{b} W_{t b}\right)+\left(P_{c} W_{t c}\right)+\left(P_{d} W_{t d}\right) \ldots . \sum W_{t}
$$

where

$I$ is the average income of a farmer (per acre)

$P$ is the average income for crop $b, c, d, \ldots$,

$W t_{b}$ is the share of the total area for crops $b, c, d, \ldots$, in the state.

Our calculations led us to the following state- and national-level opportunity costs due to agricultural land diversion (see Table C3).

\section{Table C3 | Opportunity Cost of Agricultural Land Diversion}

OPPORTUNITY COST OF AGRICULTURAL LAND DIVERSION (2017 INR/ha/YEAR)

\begin{tabular}{ll}
\hline Maharashtra & $60,335.16$ \\
\hline Jharkhand & $33,558.06$ \\
\hline Assam & $38,615.05$
\end{tabular}

Notes: ha $=$ hectare.

Sources: EANDS n.d.; WRI authors.

\section{C.3.2 Social and Environmental Impacts of Forest Land Diversion}

Forest land diversion for non-forestry purposes has environmental and social impacts, such as loss of the livelihoods of rural and tribal communities. For our calculation, we refer to Guidelines for Conducting Cost-Benefit Analysis for Projects Involving Diversion of Forest Land under the Provisions of the Forest (Conservation) Act, 1980, released by the MOEFCC in 2017 (MoEFCC 2017) to estimate these social and environmental impacts. We also use estimates for compensation provided by Verma et al. (2014) and the forest cover assessment published by the Forest Survey of India (FSI 2019) to arrive at the economic value of land diversion impact per acre of forest land diverted.

We use the following formula to arrive at the social and economic cost of forest land diversion for each of the states:

$$
N P V=\begin{aligned}
& \sum(N P V v d f * \% v d f)+(N P V m d f * \% m d f)+ \\
& (N P V v d f * \% v d f)+(N P V o f * \% o f)+(N P V l d f * \% l d f)
\end{aligned}
$$

where

$N P V$ is the average cost of forest diversion for each canopy cover, very dense forests $(v d f)$, moderately dense forests $(m d f)$, open forest $(o f)$, and less than $10 \%$ canopy $(l t f)$;

$\% v d f$ is the proportion of very dense forest to the total forest land in the state;

$\% m d f$ is the proportion of moderately dense forest to the total forest land in the state;

$\% o f$ is the proportion of open forest to the total forest land in the state; and

\%lt $f$ is the proportion of less than $10 \%$ canopy to the total forest land in the state.

\section{Table $\mathrm{C}_{4}$ | Social and Environmental Impacts of Forest} Land Diversion

SOCIAL AND ENVIRONMENTAL IMPACTS OF FOREST LAND DIVERSION (INR/ha)

\begin{tabular}{lr}
\hline Maharashtra & $31,17,179.39$ \\
\hline Jharkhand & $28,14,867.75$ \\
\hline Assam & $5,64,886.44$
\end{tabular}

Notes: ha $=$ hectare.

Sources: FSI 2019; Verma et al. 2014; WRI authors 


\section{C.3.3 Economic Value of Barren Land Use}

The impact of wasteland utilization is assumed to be minimal since the utilization would lead to neither loss of agriculture nor degradation of forest biodiversity or ecology, although wasteland could have alternative economic uses, such as commercial development. However, due to the lack of standardized data and information on lost economic opportunities, we assume the economic value, and subsequent land impact, of wasteland use for RE technology deployment to be zero.

\section{C.4 Step 4: Estimate Land-Use Impacts per MW of RE Technology Installed}

The land-use impacts for each megawatt of RE technology installed $\left(L I_{t}\right)$ is based on the economic value of land-use change and land-use patterns for RE technologies. In the baseline scenario, the power generated by 1 MW of installed RE technology capacity is substituted by an equivalent generation from the baseline technology. To account for the difference in the capacity utilization factor (CUF) of RE technology and conventional fossil-fuel-based technology, the installed capacity required in the baseline scenario is approximated by scaling the installed RE capacity by the ratio of the CUF of the RE technology to that of the coal-based technology. It is important to take this into account to avoid overestimating the net impacts for indicators.

We use the following formula to arrive at our net land-use change (Net Land Use) estimates for a land type ( $l$ ) for each RE technology $t$ :

$$
\underset{\text { Use }_{l t}}{\text { Net Land }}=\underset{\text { per } M W_{l t}}{\text { Land use }}-\underset{\text { Ler } M W_{\text {lCoal }}}{\text { Land use }} \times \frac{C U F_{t}}{C U F_{\text {coal }}}
$$

where

Land use per $M W_{l t}$ is the area of land of type I, that is, agricultural, forest, or wasteland, used to install $1 \mathrm{MW}$ of RE technology t,

Land use per $M W_{\text {Coal }}$ is the land used to install $1 \mathrm{MW}$ of coal-based technology,

$C U F_{t}$ is the capacity utilization factor of RE technology $t$, and

$C U F_{\text {coal }}$ is the CUF of coal (baseline) technology.
Finally, we use the following formula to arrive at the avoided land-use impact per megawatt of RE technology installed:

$$
L I_{t}=-\sum_{l t} N e t \text { Land Use } e_{l t} x \text { Economic impact per acre } e_{l}
$$

where

$L I_{t}$ is the avoided land-use impact per megawatt of RE technology $t$,

Net Land Use $e_{l t}$ is the net land-use change (in acres) for a land type I for RE technology t, and

Economic impact per acre ${ }_{l}$ is the economic value per acre for land type $l$, as calculated in Section C.3. 
The Fifth Intergovernmental Panel on Climate Change (IPCC) Report states that electricity is the single largest contributor to global greenhouse gas $(\mathrm{GHG})$ emissions for both current and future baseline scenarios (IPCC 2014). Electricity has and continues to play a vital role in India's economic development and society's modernization, and currently contributes 40 percent to the national $\mathrm{CO}_{2}$ emissions, per the Third Biennial Update Report (MoEFCC 2021). Further, the combustion of fossil fuel along the value chain of power generation is also responsible for carbon emissions and consequently adds to climate impacts. Thus, mitigation interventions such as the transition toward cleaner power generation, such as RE technology, have become imperative.

RE technologies reduce fossil fuel use by replacing it with renewable sources, such as solar, wind, hydro, and biomass, to generate electricity and thereby reduce the associated emissions. A study conducted by Thambi et al. (2019) projected that under the NDC scenario-that is, a 40 percent share of RE in installed capacity by 2030-a 6 percent increase in the share of $\mathrm{RE}$ to the power mix relative to 2017 would reduce emissions by $375 \mathrm{Mt} \mathrm{CO}$, by 2032

\section{D.1 Step 1: GHG Emissions Avoided}

The GHG emissions avoided $\left(E A_{R E}\right)$ due to RE technology deployment are estimated as the $\mathrm{CO}_{2}$ emissions linked to one unit of power generated (MWh) using baseline technology. In other words, the avoided GHG emissions from RE power generation are equal to the emission factor of the baseline technology $\left(\mathrm{tCO}_{2} / \mathrm{MWh}\right)$ :

$$
E A_{R E}=E F_{\text {Baseline }}
$$

We use emission factor estimates published by CEA (2019a), summarized in Table D1.

Table D1 | Summary of the Type of Fossil Fuel and the Corresponding Weighted Emission Factor of Currently Installed Conventional Power Plant in Each State

\begin{tabular}{|c|c|c|}
\hline \multicolumn{3}{|c|}{$\begin{array}{c}\text { FOSSIL FUEL AND CORRESPONDING EMISSION } \\
\text { FACTORS FOR EACH STATE }\end{array}$} \\
\hline & $\begin{array}{l}\text { FOSSIL } \\
\text { FUEL }\end{array}$ & $\begin{array}{l}\text { WEIGHTED EMISSION FACTOR } \\
\text { OF CURRENT FOSSIL-FUEL- } \\
\text { BASED POWER PLANTS } \\
\text { (tCO_/MWH }\end{array}$ \\
\hline Maharashtra & Coal & 1.02 \\
\hline Jharkhand & Coal & 0.97 \\
\hline Assam & Coal & 1.02 \\
\hline & Gas & 0.35 \\
\hline
\end{tabular}

Notes: $\mathrm{MWh}=$ megawatt-hour; $\mathrm{tCO}_{2}=$ tons carbon dioxide.

Sources: CEA 2019a.

\section{D.2 Step 2: Estimate the Social Cost of Carbon}

For our final step in estimating the climate impact of an RE technology, we use the social cost of carbon (SCC) to assign an economic value to the corresponding emissions. The SCC is the discounted economic value of climate impacts caused by emitting one metric ton of $\mathrm{CO}_{2}$ or its equivalent, into the atmosphere (Ricke et al. 2018). The SCC incorporates the effects of an increase in $\mathrm{CO}_{2}$ emission on local temperatures and ecosystems, the decline in economic and agriculture productivity, and the subsequent fall in the gross domestic product and social welfare of the population. Although various studies have used integrated assessment models to estimate the SCC, these values vary widely. These variations are mainly due to "model uncertainty" and "structural uncertainty," such as differences across models, imprecisions of structural input parameters arising from the timing and nature of the impact, and more importantly, the discount rate adopted. Thus, differences arise in productivity growth, equilibrium temperature sensitivity, and the damage function itself (Nordhaus 2017).

For our assessment, we refer to the updated SCC values estimated by Nordhaus (2017) based on the revised Dynamic Integrated Climate-Economy model. Nordhaus uses a discount rate of 4.25 percent, representing the real average annual return on investment through 2100. Discount rate assumptions are the subject of much debate, and significantly influence SCC estimates. For example, Stern (2007) uses a discount rate of 1.4 percent to obtain a significantly higher SCC estimate. However, we use the SCC estimate by Nordhaus as it is more conservative and because others, such as Weitzman (2007), have also proposed discount rate values incorporating uncertainty over long-term time frames in the range of 2-4 percent, which are closer to the value used by Nordhaus (2017). We provide the SCC values corresponding to other discount rate assumptions calculated by Nordhaus (2017) in Table D2, for reference.

The region-specific share for India in the global SCC is then calculated, based on its 9 percent share in the total discounted value of the output through 2100, translating to a country-specific SCC of $2.93 \$ / \mathrm{tCO}_{2}$ in 2015 (Nordhaus 2017). We also factor in a 3 percent rise in this value per year, in real terms, over the period to 2050, until the lifetime of the RE technology, as proposed by Nordhaus (2017). 
We also take into account the relatively high SCC value estimated by Ricke et al. (2018) for India of $85.46 \$ / \mathrm{tCO}_{2}$ under the reference scenario as an additional scenario in our analysis. All monetary values are converted to INR (2017 price levels) for the purpose of our calculations.

Table D2 | SCC Estimated by Ricke et al. (2018) and Nordhaus (2017) under Various Scenarios

\begin{tabular}{|lccc|}
\hline \multicolumn{1}{|c}{ RICKE ET AL. (2018) } & \multicolumn{2}{c|}{ NORDHAUS (2017) } \\
\hline SCENAR10 & $\begin{array}{r}\text { CSCC } \\
\left(\mathrm{S} / \mathrm{tCO}_{2}\right)\end{array}$ & $\begin{array}{l}\text { DISCOUNT } \\
\text { RATES (\%) }\end{array}$ & $\begin{array}{r}2015 \text { (S, } \\
2010 \text { PRICES) }\end{array}$ \\
\hline SSP1/RCP60 & 55.1 & 2.5 & 128.5 \\
\hline $\begin{array}{l}\text { SSP2/ } \\
\text { RCP60 } \\
\text { (reference } \\
\text { Scenario) }\end{array}$ & $\mathbf{8 5 . 4}$ & 3 & 79.1 \\
\hline $\begin{array}{l}\text { SSP3/RCP85 } \\
\text { SSP4/RCP60 }\end{array}$ & 377 & 4 & \\
& 77.2 & $\begin{array}{c}\mathbf{4 . 2 5} \\
\text { (baseline } \\
\text { discount } \\
\text { rate) }\end{array}$ & 36.3 \\
\hline SSP5/RCP85 & 73.4 & 5 & $\mathbf{3 1 . 2}$ \\
\hline
\end{tabular}

Notes: $\mathrm{SCC}=$ social cost of carbon; $\mathrm{tCO}_{2}=$ tons carbon dioxide. Sources: Ricke et al. 2018; Nordhaus 2017.
We use the following formula to estimate the climate impact $(\mathrm{Cl})$ in the year y per megawatt-hour for the electricity generated from the RE technology:

$$
C I_{y}=E A_{R E}{ }^{*} S C C_{y}
$$

where

$C I_{y}$ is the avoided climate impact per megawatt-hour of renewable electricity generated in year $y$,

$E A_{R E}$ is the avoided GHG emissions per megawatt-hour of RE power generation, and

$S C C_{y}$ is the SCC for year $y$.

Finally, the total avoided climate impact is calculated as the product of the annual electricity generated (in megawatt-hours) per megawatt of installed RE capacity and $\mathrm{CI}_{y}$. 


\section{APPENDIX E: TECHNOLOGY ASSUMPTIONS}

Table E1 | RE Technology and Baseline Technology Assumptions for Maharashtra

\begin{tabular}{|c|c|c|c|c|c|c|}
\hline \multicolumn{7}{|c|}{ MAHARASHTRA } \\
\hline \multirow{2}{*}{ TECHNICAL ASSUMPTIONS } & \multirow{2}{*}{ UNIT } & BASELINE & \multicolumn{2}{|c|}{ SOLAR } & \multirow{2}{*}{ WIND } & \multirow{2}{*}{ SHP } \\
\hline & & SUPERCRITICAL COAL & GROUND MOUNTED & ROOFTOP & & \\
\hline Project Size & MW & 1 & 1 & 1 & 1 & 1 \\
\hline Lifetime & Years & 25 & 25 & 25 & 25 & 35 \\
\hline CUF & $\%$ & 60 & 28 & 28 & 30 & 30 \\
\hline Capital Cost & INR/MW & $6,50,00,000$ & $6,05,85,000$ & $6,05,85,000$ & $6,43,01,797$ & $6,47,87,747$ \\
\hline $\begin{array}{l}\text { Fixed 0\&M Cost (as \% of Cost } \\
\text { of Capital) }\end{array}$ & $\%$ & 2.96 & 2.48 & 4.95 & 1.80 & 3.60 \\
\hline Auxiliary Consumption & $\%$ & 5.75 & 0.00 & 0.00 & 0.00 & 1.00 \\
\hline Residual Value & $\%$ & 10.00 & 10.00 & 10.00 & 10.00 & 10.00 \\
\hline Fuel Requirement & $\mathrm{t} / \mathrm{MWh}$ & 0.6 & 0 & 0 & 0 & 0 \\
\hline Fuel Cost & INR/t & 1,050 & 0 & 0 & 0 & 0 \\
\hline SDR & $\%$ & & 8 & & & \\
\hline Grid Integration Costs of RE & $\begin{array}{l}\text { INR/ } \\
\text { kWh }\end{array}$ & & 1. & & & \\
\hline
\end{tabular}

Notes: $\mathrm{CUF}=$ capacity utilization factor; $\mathrm{MW}=$ megawatt; $\mathrm{MWh}=$ megawatt-hour; $0 \& \mathrm{M}=$ operations \& management; $\mathrm{RE}=$ renewable energy; $\mathrm{SDR}=$ social discount rate; $\mathrm{SHP}=$ small hydro power; $t=$ ton (metric).

Sources; CEA 2018c; CERC 2019; JSERC 2016. 
Table E2 | RE Technology and Baseline Technology Assumptions for Jharkhand

\begin{tabular}{|c|c|c|c|c|c|}
\hline \multicolumn{6}{|c|}{ JHARKHAND } \\
\hline \multirow{2}{*}{ TECHNICAL ASSUMPTIONS } & \multirow{2}{*}{ UNIT } & BASELINE & \multicolumn{2}{|c|}{ SOLAR } & \multirow{2}{*}{ SHP } \\
\hline & & SUPERCRITICAL COAL & GROUND MOUNTED & ROOFTOP & \\
\hline Project Size & MW & 1 & 1 & 1 & 1 \\
\hline Lifetime & Years & 25 & 25 & 25 & 35 \\
\hline CUF & $\%$ & 60 & 21 & 21 & 30 \\
\hline Capital Cost & INR/MW & $6,50,00,000$ & $5,50,00,000$ & $5,50,00,000$ & $7,71,30,000$ \\
\hline $\begin{array}{l}\text { Fixed 0\&M Cost (as \% of Cost } \\
\text { of Capital) }\end{array}$ & $\%$ & 2.96 & 1.55 & 3.10 & 3.43 \\
\hline Auxiliary Consumption & $\%$ & 5.75 & 0.00 & 0.00 & 1.00 \\
\hline Residual Value & $\%$ & 10.00 & 10.00 & 10.00 & 10.00 \\
\hline Fuel Requirement & $\mathrm{t} / \mathrm{MWh}$ & 0.6 & 0 & 0 & 0 \\
\hline Fuel Cost & INR/t & 1,050 & 0 & 0 & 0 \\
\hline SDR & $\%$ & & 8 & & \\
\hline Grid Integration Costs of RE & INR/kWh & & 1.5 & & \\
\hline
\end{tabular}

Notes: CUF = capacity utilization factor; $\mathrm{MW}=$ megawatt; $\mathrm{MWh}=$ megawatt-hour; $0 \& \mathrm{M}=$ operations \& management; $\mathrm{RE}=$ renewable energy; $\mathrm{SDR}=$ social discount rate; $\mathrm{SHP}=$ small hydro power; $t=$ ton (metric).

Sources; CEA 2018c; CERC 2019; JSERC 2016. 
Table E3 | RE Technology and Baseline Technology Assumptions for Assam

\begin{tabular}{|c|c|c|c|c|c|}
\hline \multicolumn{6}{|c|}{ ASSAM } \\
\hline \multirow{2}{*}{ TECHNICAL ASSUMPTIONS } & \multirow{2}{*}{ UNIT } & BASELINE & \multicolumn{2}{|c|}{ SOLAR } & \multirow{2}{*}{ SHP } \\
\hline & & SUPERCRITICAL COAL & GROUND MOUNTED & ROOFTOP & \\
\hline Project Size & MW & 1 & 1 & 1 & 1 \\
\hline Lifetime & Years & 25 & 25 & 25 & 35 \\
\hline CUF & $\%$ & 60 & 21 & 21 & 45 \\
\hline Capital Cost & INR/MW & $6,50,00,000$ & $5,50,00,000$ & $5,50,00,000$ & $7,79,00,000$ \\
\hline $\begin{array}{l}\text { Fixed 0\&M Cost (as \% of Cost } \\
\text { of Capital) }\end{array}$ & $\%$ & 2.96 & 1.55 & 3.10 & 3.72 \\
\hline Auxiliary Consumption & $\%$ & 5.75 & 0.00 & 0.00 & 1.00 \\
\hline Residual Value & $\%$ & 10.00 & 10.00 & 10.00 & 10.00 \\
\hline Fuel Requirement & $\mathrm{t} / \mathrm{MWh}$ & 0.6 & 0 & 0 & 0 \\
\hline Fuel Cost & INR/t & 1,050 & 0 & 0 & 0 \\
\hline SDR & $\%$ & & 8 & & \\
\hline Grid Integration Costs of RE & INR/kWh & & 1.5 & & \\
\hline
\end{tabular}

\section{Supplementary Baseline Scenario (Gas) Assumption}

\begin{tabular}{|lll|}
\hline TECHNICAL ASSUMPTIONS & UNIT & $\begin{array}{l}\text { BASELINE } \\
\text { TECHNOLOGY: } \\
\text { GAS THERMAL }\end{array}$ \\
\hline Project Size & MW & 1 \\
\hline Lifetime & Years & 25 \\
\hline CUF & $\%$ & 50 \\
\hline Capital Cost & INR/MW & $5,54,99,000$ \\
\hline Fixed O\&M \% Cost of Capital & $\%$ & 3.17 \\
\hline Auxiliary Consumption & $\%$ & 4,9 \\
\hline Residual Value/Salvage Value & $\%$ & 10 \\
\hline Fuel Cost & INR/ & $1,032.65$ \\
\hline
\end{tabular}

Notes: $\mathrm{CUF}=$ capacity utilization factor; $\mathrm{MW}=$ megawatt; $\mathrm{MWh}=$ megawatt-hour; $0 \& \mathrm{M}=$ operations \& management; $\mathrm{RE}=$ renewable energy; $\mathrm{SDR}=$ social discount rate; $\mathrm{SHP}=$ small hydro power; $t=$ ton (metric).

Sources: AERC 2017; CEA 2018c; CERC 2019. 


\section{APPENDIX F: SENSITIVITY ANALYSIS}

Table F1 | Maharashtra

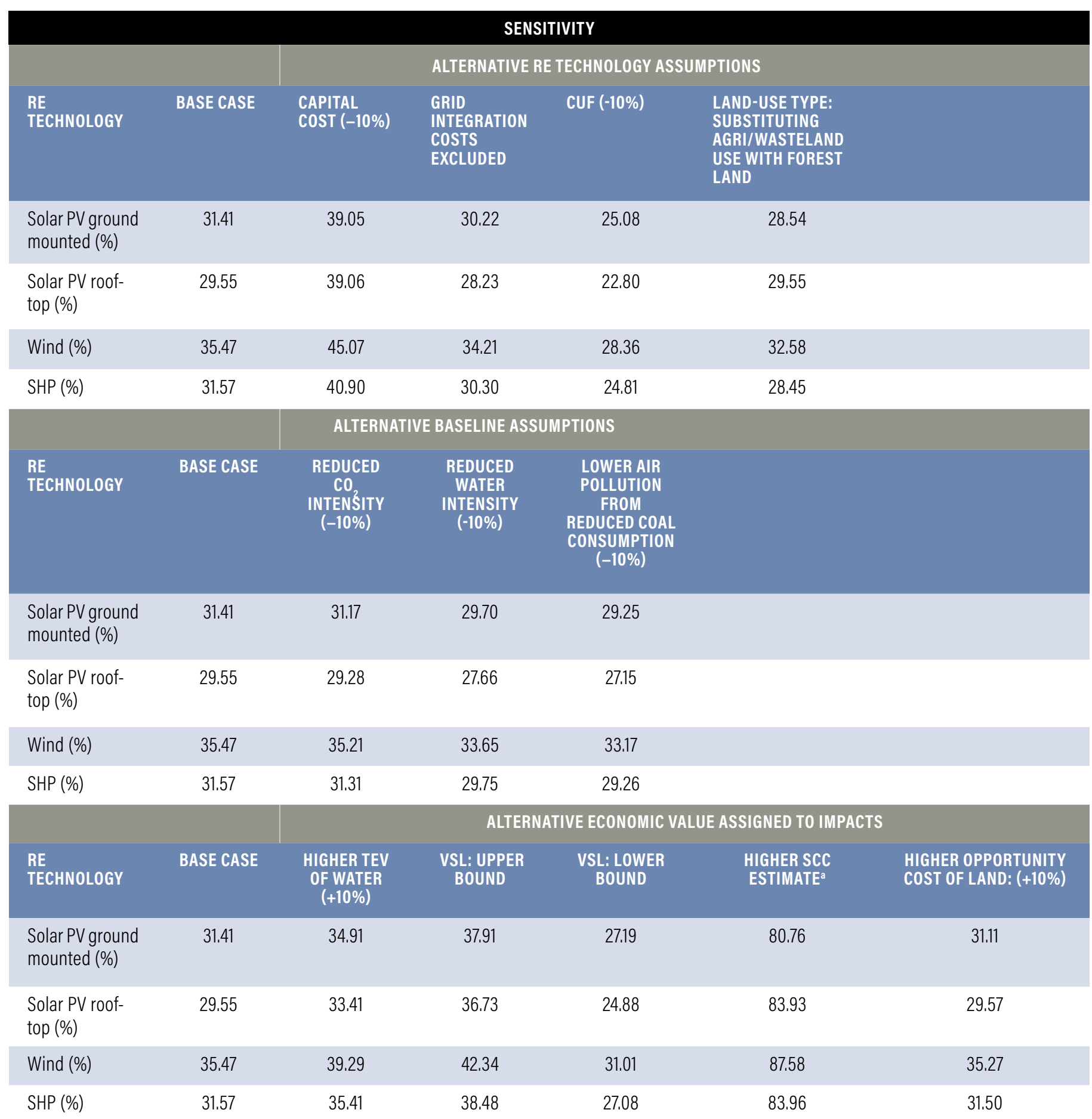

Notes: $\mathrm{CUF}=$ capacity utilization factor; $\mathrm{PV}=$ photovoltaic; $\mathrm{RE}=$ renewable energy; $\mathrm{SCC}=$ social cost of carbon; $\mathrm{SHP}=$ small hydro power; $\mathrm{TEV}=$ total economic value; VSL = value of statistical life.

Sources: a, Ricke 2020. WRI authors. 
Table F2 | Jharkhand

\begin{tabular}{|c|c|c|c|c|c|c|}
\hline \multicolumn{7}{|c|}{ SENSITIVITY } \\
\hline \multicolumn{7}{|c|}{ ALTERNATIVE RE TECHNOLOGY ASSUMPTIONS } \\
\hline $\begin{array}{l}\text { RE } \\
\text { TECHNOLOGY }\end{array}$ & BASE CASE & $\begin{array}{l}\text { CAPITAL } \\
\text { COST }(-10 \%)\end{array}$ & $\begin{array}{l}\text { GRID } \\
\text { INTEGRATION } \\
\text { COSTS } \\
\text { EXCLUDED }\end{array}$ & CUF $(+10 \%)$ & $\begin{array}{l}\text { LAND-USE TYPE: } \\
\text { SUBSTITUTING } \\
\text { AGRI/WASTELAND } \\
\text { USE WITH FOREST } \\
\text { LAND }\end{array}$ & \\
\hline $\begin{array}{l}\text { Solar PV ground } \\
\text { mounted (\%) }\end{array}$ & 25.16 & 30.72 & 24.30 & 30.24 & 22.07 & \\
\hline $\begin{array}{l}\text { Solar PV roof- } \\
\text { top (\%) }\end{array}$ & 23.36 & 29.08 & 22.47 & 28.46 & 23.36 & \\
\hline \multirow[t]{2}{*}{ SHP $(\%)$} & 23.17 & 28.96 & 22.27 & 28.35 & 21.39 & \\
\hline & & \multicolumn{3}{|c|}{ ALTERNATIVE BASELINE ASSUMPTIONS } & & \\
\hline $\begin{array}{l}\text { RE } \\
\text { TECHNOLOGY }\end{array}$ & BASE CASE & $\begin{array}{l}\text { REDUCED } \\
\text { CO } \\
\text { INTENSITY } \\
(-10 \%)\end{array}$ & $\begin{array}{l}\text { REDUCED } \\
\text { WATER } \\
\text { INTENSITY } \\
(-10 \%)\end{array}$ & $\begin{array}{l}\text { LOWER AIR } \\
\text { POLLUTION } \\
\text { FROM } \\
\text { REDUCED COAL } \\
\text { CONSUMPTION } \\
(-10 \%)\end{array}$ & & \\
\hline $\begin{array}{l}\text { Solar PV ground } \\
\text { mounted (\%) }\end{array}$ & 25.16 & 3.17 & 5.54 & 4.52 & & \\
\hline $\begin{array}{l}\text { Solar PV roof- } \\
\text { top (\%) }\end{array}$ & 23.36 & -1.02 & 2.17 & 0.98 & & \\
\hline \multirow[t]{2}{*}{ SHP $(\%)$} & 23.17 & 7.61 & 11.20 & 9.34 & & \\
\hline & & \multicolumn{5}{|c|}{ ALTERNATIVE ECONOMIC VALUE ASSIGNED TO IMPACTS } \\
\hline $\begin{array}{l}\text { RE } \\
\text { TECHNOLOGY }\end{array}$ & BASE CASE & $\begin{array}{l}\text { HIGHER TEV } \\
\text { OF WATER } \\
(+10 \%)\end{array}$ & $\begin{array}{l}\text { VSL: UPPER } \\
\text { BOUND }\end{array}$ & $\begin{array}{l}\text { VSL: LOWER } \\
\text { BOUND }\end{array}$ & $\begin{array}{l}\text { HIGHER SCC } \\
\text { ESTIMATE }^{\mathrm{a}}\end{array}$ & $\begin{array}{l}\text { HIGHER OPPORTUNITY } \\
\text { COST OF LAND: }(+10 \%)\end{array}$ \\
\hline $\begin{array}{l}\text { Solar PV ground } \\
\text { mounted (\%) }\end{array}$ & 25.16 & 25.95 & 33.90 & 19.47 & 60.23 & 25.08 \\
\hline $\begin{array}{l}\text { Solar PV roof- } \\
\text { top (\%) }\end{array}$ & 23.36 & 24.18 & 32.37 & 17.47 & 59.52 & 23.37 \\
\hline SHP (\%) & 23.17 & 24.02 & 32.30 & 17.19 & 59.82 & 23.17 \\
\hline
\end{tabular}

Notes: CUF = capacity utilization factor; $\mathrm{PV}=$ photovoltaic; $\mathrm{RE}=$ renewable energy; $\mathrm{SCC}=$ social cost of carbon; $\mathrm{SHP}=$ small hydro power; $\mathrm{TEV}=$ total economic value; $\mathrm{VSL}=$ value of statistical life.

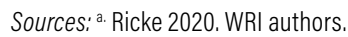


Table F3 | Assam

\begin{tabular}{|c|c|c|c|c|c|c|}
\hline \multicolumn{7}{|c|}{ SENSITIVITY } \\
\hline & & \multicolumn{5}{|c|}{ ALTERNATIVE RE TECHNOLOGY ASSUMPTIONS } \\
\hline $\begin{array}{l}\text { RE } \\
\text { TECHNOLOGY }\end{array}$ & BASE CASE & $\begin{array}{l}\text { CAPITAL } \\
\text { COST }(-10 \%)\end{array}$ & $\begin{array}{l}\text { GRID } \\
\text { INTEGRATION } \\
\text { COSTS } \\
\text { EXCLUDED }\end{array}$ & $\begin{array}{l}\text { CUF (SOLAR: } \\
+10 \% ; \text { SHP: } \\
-10 \%)\end{array}$ & $\begin{array}{l}\text { LAND-USE TYPE: } \\
\text { SUBSTITUTING } \\
\text { AGRI/WASTELAND } \\
\text { USE WITH FOREST } \\
\text { LAND }\end{array}$ & \\
\hline $\begin{array}{l}\text { Solar PV ground } \\
\text { mounted (\%) }\end{array}$ & 5.67 & 8.00 & 15.62 & 7.66 & 4.40 & \\
\hline $\begin{array}{l}\text { Solar PV roof- } \\
\text { top (\%) }\end{array}$ & 2.33 & 4.71 & 13.0 & 4.33 & 2.33 & \\
\hline \multirow[t]{2}{*}{ SHP $(\%)$} & 11.45 & NA & 30.65 & 7.52 & 11.11 & \\
\hline & & \multicolumn{5}{|c|}{ ALTERNATIVE BASELINE ASSUMPTIONS } \\
\hline $\begin{array}{l}\text { RE } \\
\text { TECHNOLOGY }\end{array}$ & BASE CASE & $\begin{array}{l}\text { REDUCED } \\
\text { CO }_{2} \\
\text { INTENSITY } \\
(-10 \%)\end{array}$ & $\begin{array}{l}\text { REDUCED } \\
\text { WATER } \\
\text { INTENSITY } \\
(-10 \%)\end{array}$ & $\begin{array}{l}\text { LOWER AIR } \\
\text { POLLUTION } \\
\text { FROM } \\
\text { REDUCED COAL } \\
\text { CONSUMPTION } \\
(-10 \%)\end{array}$ & $\begin{array}{l}\text { ALTERNATIVE } \\
\text { TECHNOLOGY: GAS } \\
\text { (EXCLUDING GRID } \\
\text { INTEGRATION COSTS }\end{array}$ & \\
\hline $\begin{array}{l}\text { Solar PV ground } \\
\text { mounted (\%) }\end{array}$ & 5.67 & 3.17 & 5.54 & 4.52 & 6.04 & \\
\hline $\begin{array}{l}\text { Solar PV roof- } \\
\text { top (\%) }\end{array}$ & 2.33 & -1.02 & 2.17 & 0.98 & 2.58 & \\
\hline \multirow[t]{2}{*}{ SHP (\%) } & 11.45 & 7.61 & 11.20 & 9.34 & 13.44 & \\
\hline & & \multicolumn{5}{|c|}{ ALTERNATIVE ECONOMIC VALUE ASSIGNED TO IMPACTS } \\
\hline $\begin{array}{l}\text { RE } \\
\text { TECHNOLOGY }\end{array}$ & BASE CASE & $\begin{array}{l}\text { HIGHER TEV } \\
\text { OF WATER } \\
(+10 \%)\end{array}$ & $\begin{array}{l}\text { VSL: UPPER } \\
\text { BOUND }\end{array}$ & $\begin{array}{l}\text { VSL: LOWER } \\
\text { BOUND }\end{array}$ & $\begin{array}{l}\text { HIGHER SCC } \\
\text { ESTIMATE }^{\mathrm{a}}\end{array}$ & $\begin{array}{l}\text { HIGHER OPPORTUNITY } \\
\text { COST OF LAND: }(+10 \%)\end{array}$ \\
\hline $\begin{array}{l}\text { Solar PV ground } \\
\text { mounted (\%) }\end{array}$ & 5.67 & 5.95 & 7.00 & 4.78 & 44.85 & 5.64 \\
\hline $\begin{array}{l}\text { Solar PV roof- } \\
\text { top (\%) }\end{array}$ & 2.33 & 2.65 & 3.83 & 1.29 & 42.61 & 2.33 \\
\hline SHP (\%) & 11.45 & 11.95 & 12.60 & 10.69 & 91.36 & 11.32 \\
\hline
\end{tabular}

Notes: $\mathrm{PV}$ = photovoltaic; $\mathrm{RE}=$ renewable energy; $\mathrm{SCC}=$ social cost of carbon; $\mathrm{SHP}=$ small hydro power; $\mathrm{TEV}$ = total economic value; $\mathrm{VSL}=$ value of statistical life. Sources: a Ricke 2020. WRI authors. 


\section{REFERENCES}

AERC (Assam Electricity Regulatory Commission). 2015. "Assam Grid Interactive Solar PV Systems Regulations 2015," May 2. Guwahati, Assam: AERC. https://power.assam.gov.in/sites/default/files/AERC-GridInteractive-Solar-PV-Systems-Regulations-2015.pdf.

AERC. 2017. Draft-Assam Electricity Regulatory Commission (Terms and Conditions for Tariff Determination from Renewable Energy Sources), Regulations 2017. July 21. http://aerc.nic.in/Draft\%20AERC(Terms\%20 and\%20Conditions\%20for\%20Tariff\%20Determination\%20from\%20 Renewable\%20Energy\%20Sources),\%20Regulations\%202017.pdf.

Anderson, D., H. Moggridge, P. Warren, and J. Shucksmith. 2015. "The Impacts of 'Run-of-River' Hydropower on the Physical and Ecological Condition of Rivers." Water and Environment Journal 29 (2): 268-76. doi: https://doi.org/10.1111/wej.12101.

APGCL (Assam Power Generation Corporation Limited). 2013. Social Due Diligence Report Tranche 1: (Lakwa Replacement Power Plant-70-MW). Draft for Consultation. India: Assam Power Sector Investment Program. Guwahati, Assam: APGCL. September. https://www.adb.org/sites/default/ files/project-document/78715/47101-001-ind-sdd.pdf.

Apte, J.S., J.D. Marshall, A.J. Cohen, and M. Brauer. 2015. "Addressing Global

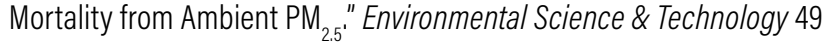
(13): 8057-8066. doi: 10.1021/acs.est.5b01236.

Bhushan C., S. Banerjee, and S. Agarwal. 2020. Just Transition in India: An Inquiry into the Challenges and Opportunities for a Post-Coal Future. New Delhi: Sustainability Innovations and Advisories Pvt. Ltd.

CCEA (Cabinet Committee on Economic Affairs). 2019. "Cabinet Approves Launch Kisan Urja Suraksha Evam Utthaan Mahabhiyan." Press release. 2019. pib.gov.in/Pressreleaseshare.aspx?PRID=1565274.

CEA (Central Electricity Authority). 2018a. CEA Annual Report 2018. New Delhi: CEA, Ministry of Power, Government of India. https://cea.nic.in/old/ reports/annual/annualreports/annual_report-2018.pdf.

CEA. 2018b. Report of the Technical Committee on Study of Optimal Location of Various Types of Balancing Energy Sources/Energy Storage Devices to Facilitate Grid Integration of Renewable Energy Sources and Associated Issues. New Delhi: CEA, Ministry of Power, Government of India. https://cea.nic.in/wp-content/uploads/2020/03/report.pdf.

CEA. 2018c. National Electricity Plan (Volume 1) Generation. New Delhi: CEA Ministry of Power, Government of India. https://cea.nic.in/wp-content/ uploads/2020/04/nep_jan_2018.pdf.

CEA. 2019a. CEA Annual Report 2019. New Delhi: CEA, Ministry of Power, Government of India. https://cea.nic.in/old/reports/annual/annualreports/ annual_report-2019.pdf.

CEA. 2019b. CEA C02 Baseline Database. Versions 15.0. New Delhi: CEA, Ministry of Power, Government of India. https://cea.nic.in/cdm-co2baseline-database/?lang=en.

CEA. 2020a. CEA Plant-Wise Details of RE Installed Capacity Merged All States, New Delhi: CEA, Ministry of Power, Government of India. https:// cea.nic.in/old/reports/others/planning/rpm/Plant-wise\%20details\%20 of\%20RE\%20Installed\%20Capacity-merged.pdf.

CEA. 2020b. CEA Annual Generation Programme 2020. New Delhi: CEA, Ministry of Power, Government of India. https://cea.nic.in/wp-content/ uploads/annual_generation/2019/gen_target-2020.pdf.
CEA. 2020c. CEA Annual Report 2019-20. New Delhi: CEA, Ministry of Power, Government of India. https://cea.nic.in/old/reports/circulars/2020/146.pdf.

CEA. n.d. Thermal Performance Evaluation \& Climate Change DivisionOther Reports. https://cea.nic.in/old/tpeandce.html. Accessed August 24, 2020.

CEEW (Council on Energy, Environment and Water) and SCGJ (Skill Council for Green Jobs). 2019. Future Skills and Job Creation with Renewable Energy in India: Assessing the Co-Benefits of Decarbonizing the Power Sector. A COBENEFITS Study. CEEW and SCGL: New Delhi. October. https://www.ceew.in/sites/default/files/future.pdf.

CERC (Central Electricity Regulatory Commission). 2018a. "Central Electricity Regulatory Commission Determination of Levellised Generic Tariff for FY 2018-19." Tariff Order. http://cercind.gov.in/2018/orders/02.pdf.

CERC. 2018b. "Pro-Froma for Furnishing Actual Annual Performance/ Operational Data for the Coal Based Thermal Generating Station for the 5 Year Period from 2012-13 to 2016-17: Bongaigaon Thermal Power Station." http://cercind.gov.in/2018/draft_reg/0\&M_data/Generation\%20Data/ NTPC/Bongaigaon.pdf.

\section{CERC. 2019. Explanatory Memorandum on Draft Central Electricity} Regulatory Commission (Terms and Conditions of Tariff) Regulations, 2019. New Delhi: CERC. https://cercind.gov.in/2018/draft_reg/comment_ Reg_01-04-19/EM.pdf.

Chaturvedi, V., P.N. Koti, R. Sugam, K. Neog, and M. Hejazi. 2017. Implications of Shared Socio-Economic Pathways for India's Long Term Electricity Generation and Associated Water Demands. Working paper. New Delhi: Council on Energy, Environment and Water (CEEW). https://www.ceew. in/sites/default/files/CEEW-Implications-of-Shared-Socio-EconomicPathways-for-India-Longterm.pdf.

Chaturvedi, V., P.N. Koti, and A. Chordia. 2018. Sustainable Development, Uncertainties, and India's Climate Policy: Pathways towards Nationally Determined Contribution and Mid-Century Strategy. New Delhi: Council on Energy, Environment and Water (CEEW). https://www.ceew.in/sites/ default/files/CEEW_Sustainable_Development_Uncertainties_India_ Climate_Policy_30Äpr18.pdf.

Chen, T.-M., J. Gokhale, S. Shofer, and W.G. Kuschner. 2007. "Outdoor Air Pollution: Nitrogen Dioxide, Sulfur Dioxide, and Carbon Monoxide Health Effects." The American Journal of the Medical Sciences 333 (4): 249-56. doi:10.1097/MAJ.0b013e31803b900f.

CPR (Centre for Policy Research). 2018. "Understanding the Impacts of Land Use Change." Blog. July 18. https://www.cprindia.org/news/7047.

Cropper, M.L., S. Guttikunda, P. Jawahar, Z. Lazri, K. Malik, X.-P. Song, and X. Yao. 2019. "Applying Benefit-Cost Analysis to Air Pollution Control in the Indian Power Sector." Journal of Benefit-Cost Analysis 10 (S1): 185-205. doi:10.1017/bca.2018.27.

Denholm, P., W. Cole, A.W. Frazier, K. Podkaminer, and N. Blair. 2021. The Four Phases of Storage Deployment: A Framework for the Expanding Role of Storage in the U.S. Power System. Storage Futures Study. Golden, Colorado: National Renewable Energy Laboratory. https://www.nrel.gov/docs/ fy210sti/77480.pdf.

EANDS. n.d. "Land Use Statistics at a Glance 2007-08 to 2017-18." https:// eands.dacnet.nic.in/LUS_1999_2004.htm. Accessed August 25, 2020. 
EPA (U.S. Environmental Protection Agency), 2018. "Emission Factors for Greenhouse Gas Inventories." Data Sheet. https://www.epa.gov/sites/ default/files/2018-03/documents/emission-factors_mar_2018_0.pdf.

EPA. n.d. "Natural Gas Combustion." Chapter 1, Section 4, in Compilation of Air Pollutant Emissions Factors (AP-42). Washington, DC: EPA. https:// www3.epa.gov/ttnchie1/ap42/ch01/final/c01s04.pdf. Accessed May 24, 2021.

European Commission. 2008. Guide to Cost-Benefit Analysis of Investment Projects. Brusse/s: European Commission. https://ec.europa.eu/regional_ policy/sources/docgener/guides/cost/guide2008_en.pdf.

FSI (Forest Survey of India), 2019. "Forest Cover." Chapter 2 in India State of Forest Report 2019. Dehradun, Uttarakhand, India: FSI, Ministry of Environment, Forest and Climate Change, Government of India. https://fsi. nic.in/isfr19/vol1/chapter2.pdf.

Garg, V., D. Narayanswamy, K. Ganesan, B. Viswanathan. 2019. India's Energy Transition: The Cost of Meeting Air Pollution Standards in the CoalFired Electricity Sector. Issue Brief. Manitoba, Canada: The International Institute of Sustainable Development, https://www.iisd.org/system/ files/2020-08/india-energy-transition-air-pollution-standards.pdf.

Gawande, A. and P. Chaudhry. 2019. "Environmental and Social Impacts of Solar Energy: A Viewpoint with Reference to India." Jharkhand Journal of Development and Management Studies 17: (2) 8115-25. https://www.xiss. ac.in/JJDMS/Vol17/Issue2/pdf/5.pdf.

Global Energy Observatory, Google, KTH Royal Institute of Technology in Stockholm, Enipedia, and World Resources Institute. 2018. Global Power Plant Database. Published on Resource Watch and Google Earth Engine. https://datasets.wri.org/dataset/globalpowerplantdatabase.

Gulati, A., S. Manchanda, and R. Kacker. 2016. "Harvesting Solar Power in India." ZEF Working Paper Series, No. 152. Bonn: University of Bonn, Center for Development Research (ZEF), doi:10.2139/ssrn.2851743.

Gunatilake, H., K. Ganesan, and E. Bacani. 2014. Valuation of Health Impacts of Air Pollution from Power Plants in Asia: A Practical Guide. Manila: Asian Development Bank (ADB).

Guttikunda, S.K., and P. Jawahar. 2014. "Atmospheric Emissions and Pollution from the Coal-Fired Thermal Power Plants in India." Atmospheric Environment 92 (August): 449-60, doi:10.1016/j,atmosenv.2014.04.057.

Hernandez, R.R., S.B. Easter, M.L. Murphy-Mariscal, F.T. Maestre, M. Tavassoli, E.B. Allen, C.W. Barrows, et al. 2014. "Environmental Impacts of Utility-Scale Solar Energy." Renewable and Sustainable Energy Reviews 29: 766-79.

Hingne, A., J.-C. Altamirano, A. Mitra, R. Song, and N. Singh. 2020 "Assessing the Sustainable Development Impacts of Renewable Power Technologies in India: An Economic Rate of Return Framework." Working Paper. Washington, DC: World Resources Institute. https:// www.wri.org/ publication/sustainable-development-impactsrenewables-economicreturns.

Hofste, R., S. Kuzma, S. Walker, E. Sutanudjaja, M. Bierkens, M. Kuijper, M. Faneca Sanchez, et al. 2019. "Aqueduct 3.0: Updated DecisionRelevant Global Water Risk Indicators." WRI Publications. doi:10.46830/ writn.18.00146.
IEA (International Energy Agency), 2020. Renewable Energy Market Update: Outlook for 2020 and 2021. Paris: IEA. doi:10.1787/afbc8c1d-en.

IEA. 2021. Net Zero by 2050: A Roadmap for the Global Energy Sector. Paris: IEA. https://www.iea.org/reports/net-zero-by-2050.

IPCC (Intergovernmental Panel on Climate Change). 2014. Climate Change 2014: Synthesis Report. Contribution of Working Groups I, II, and III to the Fifth Assessment Report of the Intergovernmental Panel on Climate Change, edited by R.K. Pachauri and L.A. Meyer. Geneva: IPCC. https:// www.ipcc.ch/site/assets/uploads/2018/05/SYR_AR5_FINAL_full_wcover. pdf.

IRENA (International Renewable Energy Agency) and WRI (World Resources Institute). 2018. "Water Use in India's Power Generation: Impact of Renewables and Improved Cooling Technologies to 2030." Methodology and Data Sources. Abu Dhabi: IRENA and Washington, DC: WRI.

Jairaj, B., P. Deka, S. Martin, and S. Kumar. 2017. "Can Renewable Energy Jobs Help Reduce Poverty in India?". Washington, DC: World Resources Institute.

JSERC (Jharkhand State Electricity Regulatory Commission). 2016. "Jharkhand State Electricity Regulatory Commission (Determination of Tariff for Procurement of Power from Small Hydro Power Projects) Regulation, 2016." December 8. http://jserc.org/pdf/ regulations/25_2_2017.pdf.

Kiesecker, J., S. Baruch-Mordo, M. Heiner, D. Negandhi, J. Oakleaf, C. Kennedy, and P. Chauhan. 2020. "Renewable Energy and Land Use in India: A Vision to Facilitate Sustainable Development." Sustainability 12 (1): 281. doi:10.3390/su12010281.

Kumar, A., and S. Thapar. 2017. Addressing Land Issues for Utility Scale Renewable Energy Deployment in India. New Delhi: TERI School of Advanced Studies. https://shaktifoundation.in/wp-content/ uploads/2018/01/Study-Report-Addressing-Land-Issues-for-Utility-ScaleRenewable-Energy-Deployment-in-India.pdf.

Kumar, P., and B. Jairaj. 2019. "How Can India Better Regulate the Water Consumption of Its Thermal Power Plants?" Blog. June 13. World Resources Institute India. https://wri-india.org/blog/how-can-india-better-regulatewater-consumption-its-thermal-power-plants.

LARR (Land Acquisition, Rehabilitation and Resettlement). 2013. "Right to Fair Compensation and Transparency in Land Acquisition, Rehabilitation and Resettlement Act, 2013." New Delhi: The Gazette of India. September 27. https://dolr.gov.in/sites/default/files/Right\%20to\%20Fair\%20 Compensation\%20and\%20Transparency\%20in\%20Land\%20 Acquisition\%2C\%20Rehabilitation\%20and\%20Resettlement\%20 Act\%2C\%202013.pdf.

Luo, T., D. Krishnan, and S. Sen. 2018. "Parched Power: Water Demands, Risks, and Opportunities for India's Power Sector." Working Paper. Washington, DC: World Resources Institute.

Majumder, A., and S. Madheswaran. 2018. "Value of Statistical Life in India: A Hedonic Wage Approach." Working Paper. Bengaluru: The Institute for Social and Economic Change.

MEDA (Maharashtra Energy Development Agency). 2016. "List of Potential Sites Vetted by NIWE for Wind Power Projects in Maharashtra (WPD>200 $\mathrm{W} / \mathrm{m}^{2}$ at $50 \mathrm{mAGL}$ ) (as on 31.03.2016)." Word document. https://mahaurja. $\mathrm{com} / \mathrm{meda} / \mathrm{data} /$ grid_wind_power/Windy\%20sites\%20in\%20MAH.PDF. 
MERC (Maharashtra Electricity Regulatory Commission). 2019.

"Maharashtra Electricity Regulatory Commission (Terms and Conditions for Determination of Renewable Energy Tariff) Regulations, 2019." Available for download at: https://www.merc.govin/mercweb/faces/merc/ common/outputClient.xhtml.

MNRE (Ministry of New and Renewable Energy). 2019. MNRE Annual Report 2018-2019. New Delhi: MNRE. https://mnre.gov.in/img/documents/ uploads/0ce0bba7b9f24b32aed4d89265d6b067.pdf.

MNRE. 2020. MNRE Annual Report 2019-2020. New Delhi: MNRE. https:// mnre.gov.in/img/documents/uploads/file_f-1597797108502.pdf.

MNRE(a). n.d. "Ministry of New Government of India." https://mnre.gov.in/, Accessed May 25, 2021.

MNRE(b). n.d. "Overview | Ministry of New and Renewable Energy, Government of India." Accessed May 25, 2021. https://mnre.gov.in/newtechnologies/overview.

MoEFCC (Ministry of Environment, Forests and Climate Change). 2010. "Environmental Clearance: 2X660 MW (Stage-III) Mouda Thermal Power Plant Project at Villages Mouda, Kumbhari, Lapka, Koradi, and Rahli, in Taluk Mouda, in District Nagpur in Maharashtra." Letter from Dr. P.L. Ahujarai, Scientist. December 30. https://www.ntpc.co.in/download/ mouda-stpp-stage-ii-2x660-mw.

MoEFCC. 2015. "Thermal Plant Emission Notification December 2015." December 7. https://vindhyabachao.org/embeds/thermal/Thermal_ Plant_Emission_Notification_Dec_2015.pdf.

MoEFCC. 2017. "MOEFCC: Guidelines for Conducting CBA for Projects Involving Diversion of Forest Land under the Provision of the Forest Act 1980." Letter from N. Saxena, Sr. Asst. IG of Forests. August 1. http://forestsclearance.nic.in/writereaddata/public_display/ schemes/2111309857\$7\%2069\%202011\%20FC\%20PT.pdf.

MoEFCC. 2021. India: Third Biennial Update Report to the United Nations Framework Convention on Climate Change. New Delhi: MoEFCC. https:// unfccc.int/sites/default/files/resource/INDIA_\%20BUR-3_20.02.2021_ High.pdf

MoEL (Ministry of Labour \& Employment). 2017. "Order on Minimum Rates of Wages and Dearness Allowance." April 20. https://clc.govin/clc/ node/561.

MoHFW. (Ministry of Health and Family Welfare). 2014. Healthcare Utilization \& Expenditure in India: State Fact Sheets. New Delhi: MoHFW, Government of India. https://nhsrcindia.org/sites/default/files/2021-06/ State\%20Fact\%20Sheets_Health\%20care\%20Utilization\%20and\%20 Expenditure\%20in\%20India.pdf.

Mortensen, N.G. 2013. Planning and Development of Wind Farms: Wind Resource Assessment and Siting. Department of Wind Energy, Technical University of Denmark. https://backend.orbit.dtu.dk/ws/portalfiles/ portal/51569749/Planning_and_Development_of_Wind_Farms.pdf.

MoSPI (Ministry of Statistics \& Programme Implementation). 2014. "Participation in Economy." Chapter 4 in Women and Men in India-2014. New Delhi: MoSPI, Government of India. http://mospi.nic.in/sites/default/ files/reports_and_publication/statistical_publication/social_statistics/ Chapter_4.pdf.

MoSPI. 2018. Energy Statistics 2018. New Delhi: MoSPI, Government of India. http://mospi.nic.in/sites/default/files/publication_reports/Energy_ Statistics_2018.pdf.
MoSPI. 2019. Energy Statistics 2019. New Delhi: MoSPI, Government of India. http://www.indiaenvironmentportal.org.in/files/file/Energy\%20 Statistics\%202019.pdf.

MoSPI. 2020. Energy Statistics 2020. New Delhi: MoSPI, Government of India. http://mospi.nic.in/sites/default/files/publication_reports/ ES_2020_240420m.pdf.

MoSPI. n.d. "4.5 Nine-Fold Classification of Land Use | Ministry of Statistics and Program Implementation | Government of India." http://mospi.nic. in/45-nine-fold-classification-land-use. Accessed August 25, 2020.

Murty, M.N., M. Panda, and W. Joe. 2020. "Estimating Social Time Preference Rate for India: Lower Discount Rates for Climate Change Mitigation and Other Long Run Investment Projects." Working Paper. New Delhi: Institute of Economic Growth. http://iegindia.org/upload/profile_ publication/doc-310320_153806wp388.pdf.

NACAAP (National Association of Clean Air Agencies). 2011. PM 2 Modeling Implementation for Projects Subject to National Ambient Air Quality Demonstration Requirements Pursuant to New Source Review. Washington, DC: NACAAP. http://www.4cleanair.org/sites/default/files/01072011-NACAA PM2.5ModelingWorkgroupReport-FINAL_3.pdf.

NITI Aayog. 2015. Report on Expert Group on 175 GW RE by 2022. New Delhi: NITI Aayog. https://smartnet.niua.org/content/af9a83ce-0de2-46d4-b829e3d886af1d6c

NIWE (National Institute of Wind Energy). n.d. "National Institute of Wind Energy: Wind Power Potential at 100m agl." https://niwe.res.in/ department_wra_100m\%20agl.php. Accessed August 25, 2020.

Nordhaus, W.D. 2017. "Revisiting the Social Cost of Carbon." Proceedings of the National Academy of Sciences 114 (7): 1518-23. doi:10.1073/ pnas.1609244114.

OECD (Organization for Economic Co-Operation and Development). 2012. Mortality Risk Valuation in Environment, Health and Transport Policies. OECD Publishing. https://doi.org/10.1787/9789264130807-en.

OECD, IEA, and IRENA. 2017. Perspectives for the Energy Transition: Investment Needs for a Low-Carbon Energy System. https://www.irena. org/-/media/Files/IRENA/Agency/Publication/2017/Mar/Perspectives_ for_the_Energy_Transition_2017.pdf?la $=$ en\&hash $=56436956$ B74DBD22 A9C6309ED76E3924A879D0C7.

Palchak, D., J. Cochran, A. Ehlen, B. McBennett, M. Milligan, I. Chernyakhovskiy, R. Deshmukh, et al. 2017. Greening the Grid: Pathways to Integrate 175 Gigawatts of Renewable Energy into India's Electric Grid, Vol. I-National Study, Golden, Colorado: National Renewable Energy Laboratory, doi:https://doi.org/10.2172/1369138.

PIB (Press Information Bureau). 2019. "Cabinet Approves Measures to Promote Hydro Power Sector." New Delhi: PIB. March 7. pib.gov.in/ Pressreleaseshare.aspx?PRID=1567817.

PIB. 2021. "National Statement by Prime Minister Shri Narendra Modi at COP26 Summit in Glasgow." November 1. https://pib.gov.in/ PressReleseDetailm.aspx?PRID=1768712.

Rai, R., Y. Zhang, B. Paudel, B. Acharya, and L. Basnet. 2018. "Land Use and Land Cover Dynamics and Assessing the Ecosystem Service Values in the Trans-Boundary Gandaki River Basin, Central Himalayas." Sustainability 10 (9): 3052. doi:10.3390/su10093052. 
Rich, D., K.H. Olsen, A. Soezer, C. Campbell-Durufle, D.D. Desgain, F. Bakhtiari, G. Esambe, et al. 2018. ICAT Sustainable Development Guidance, Initiative for Climate Action Transparency. https:// climateactiontransparency.org/wp-content/uploads/2018/05/ICATSustainable-Development-Guidance-May-2018.pdf.

Ricke, K., L. Drouet, K. Caldeira, and M. Tavoni. 2018، "Country-Level Social Cost of Carbon." Nature Climate Change 8 (10): 895-900. doi:10.1038/ s41558-018-0282-y.

Ridley, M., and D. Boland. 2015. "Integrating Water Stress into Corporate Bond Credit Analysis". Deutsche Gesellschaft für Internationale Zusammenarbeit, Natural Capital Declaration, and Verein für Umweltmanagement und Nachhaltigkeit in Finanzinstituten. https://naturalcapital.finance/wp-content/uploads/2018/11/INTEGRATINGWATER-STRESS-REPORT_FINAL.pdf.

SEDAC (Socioeconomic Data and Applications Center). n.d. "Gridded Population of the World (GPW), v4 | SEDAC." Data Collection. https://sedac. ciesin.columbia.edu/data/collection/gpw-v4. Accessed May 23, 2021.

Srinivasan, S., N. Roshan, S. Guttikunda, A. Kanudia, S. Saif, and J. Asundi. 2018. Benefit Cost Analysis of Emission Standards for Coal-Based Thermal Power Plants in India. Bengaluru: Center for Study of Science, Technology and Policy. https://shaktifoundation.in/wp-content/uploads/2018/07/ Benefit-cost-analysis-of-emission-standards-for-coal-based-thermalpower-plants-in-India-1.pdf.

Stern, N. 2007. The Economics of Climate Change: The Stern Review. Cambridge: Cambridge University Press, doi:10.1017/CB09780511817434.
Tawalbeh, M., A. Al-0thman, F. Kafiah, E. Abdelsalam, F. Almomani, and M. Alkasrawi. 2021. "Environmental Impacts of Solar Photovoltaic Systems: A Critical Review of Recent Progress and Future Outlook." Science of The Total Environment 759 (March): 143528, doi:10.1016/j.scitotenv.2020.143528.

Thambi, S., A. Bhatacharya, and O. Fricko. 2019. "India's Energy and Emissions Outlook: Results from India Energy Model." New Delhi: NITI Aayog.

UNDP (United Nations Development Programme). 2020. The Next Frontier Human Development and the Anthropocene. New York: UNDP. http://hdr. undp.org/sites/default/files/hdr2020.pdf.

UNFCCC (United Nations Framework Convention on Climate Change). 2015. "India's Intended Nationally Determined Contribution: Working Towards Climate Justice." https://www4.unfccc.int/sites/ndcstaging/ PublishedDocuments/India\%20First/INDIA\%20INDC\%20T0\%20UNFCCC. pdf.

Verma, M., D. Negandhi, A.K. Wahal, R. Kumar, G.A. Kinhal, and A. Kumar. 2014. Revision of Rates of NPV Applicable for Different Class/Category of Forests. Bhopal, Madhya Pradesh, India: Indian Institute of Forest Management.

Walvekar, P.P., B.R. Gurjar, and A.S. Nagpure. 2019. "Stack Emissions and Health Risk Integrated (SEHRI) Model: A Tool for Stack Emissions and Health Risk Modeling." Air Quality, Atmosphere \& Health 12 (12): 1483-93. doi:10.1007/s11869-019-00766-w.

Weitzman, M.L. 2007. "A Review of the Stern Review on the Economics of Climate Change." Journal of Economic Literature 45 (3): 703-24. 


\section{ACKNOWLEDGMENTS}

This Working Paper has been produced under the International Climate Initiative (IKI). The German Federal Ministry for the Environment, Nature Conservation and Nuclear Safety (BMU) supports this initiative on the basis of a decision adopted by the German Bundestag.
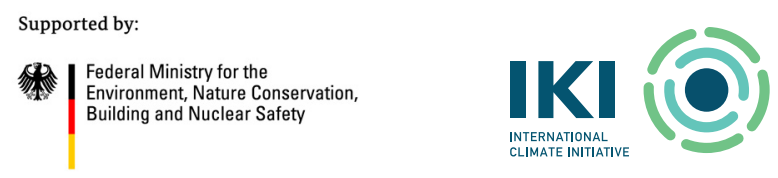

based on a decision of the German Bundestag

\section{ABOUT THE AUTHORS}

Tejaswini Kulkarni is a former Project Associate with the Climate Program at WRI India.

Ashwini Hingne is a Senior Manager with the Climate Program at WRI India.

Contact: Ashwini.Hingne@wri.org

Varun Agarwal is a Senior Project Associate at the Climate Program at WRI India.

Contact: Varun.Agarwal@wri.org

Juan Carlos Altamirano is an Economist on the Economics Team at WRI. Contact: jcaltamirano@wri.org

We would like to thank WRI colleagues Neelam Singh, Ulka Kelkar, Shahana Chattaraj, Ajay Nagpure, Janhavi Mane, Prashant Singh, Bhavay Sharma, Ritesh Kumar, Apurba Mitra, Vishwajeet Poojary, Pamli Deka, Bharath Jairaj, Deepak Krishnan, Masfick Hazarika, Deepak Gupta, and Zhe Liu whose insights and suggestions helped improve this paper. We are also grateful to our external reviewers Meeta Keswani Mehra (Jawaharlal Nehru University), Souvik Bhattacharjya (The Energy and Resources Institute), and Arnab Deb (Morningstar Inc.) for their valuable feedback, which was instrumental in the publication of this paper.

We are grateful for the administrative, editorial, and design support of Renee Pineda, Santhosh Matthew Paul, Rebecca Feldman, LSF Editorial, Romain Warnault and Jen Lockard. 


\section{ABOUT WRI}

World Resources Institute is a global research organization that turns big ideas into action at the nexus of environment, economic opportunity, and human well-being.

\section{Our Challenge}

Natural resources are at the foundation of economic opportunity and human well-being. But today, we are depleting Earth's resources at rates that are not sustainable, endangering economies and people's lives. People depend on clean water, fertile land, healthy forests, and a stable climate. Livable cities and clean energy are essential for a sustainable planet. We must address these urgent, global challenges this decade.

\section{Our Vision}

We envision an equitable and prosperous planet driven by the wise management of natural resources. We aspire to create a world where the actions of government, business, and communities combine to eliminate poverty and sustain the natural environment for all people.

\section{Our Approach}

\section{COUNT IT}

We start with data. We conduct independent research and draw on the latest technology to develop new insights and recommendations. Our rigorous analysis identifies risks, unveils opportunities, and informs smart strategies. We focus our efforts on influential and emerging economies where the future of sustainability will be determined.

\section{CHANGE IT}

We use our research to influence government policies, business strategies, and civil society action. We test projects with communities, companies, and government agencies to build a strong evidence base. Then, we work with partners to deliver change on the ground that alleviates poverty and strengthens society. We hold ourselves accountable to ensure our outcomes will be bold and enduring.

\section{SCALE IT}

We don't think small. Once tested, we work with partners to adopt and expand our efforts regionally and globally. We engage with decisionmakers to carry out our ideas and elevate our impact. We measure success through government and business actions that improve people's lives and sustain a healthy environment. 